\title{
20. PROVENANCE AND SEDIMENTOLOGIC VARIATIONS OF TURBIDITE AND SLUMP DEPOSITS AT SITES 955 AND $956^{1}$
}

\author{
Patrick M. Goldstrand ${ }^{2}$
}

\begin{abstract}
At two of the seven sites drilled during Leg 157, located south of the Canary Islands (Sites 955 and 956), more than 1000 thinly bedded to finely laminated volcaniclastic and nonvolcaniclastic silt and sand turbidite units interbedded within thick sequences of hemipelagic mud were recovered. The sediments range in age from Pleistocene to middle Miocene. Turbidite deposits composed mostly of volcaniclastic detritus are related to known periods of volcanism in the Canary Islands. The nonvolcaniclastic turbidites include various mixtures of quartz and foraminifer sand and silt derived from the continental margin of northwestern Africa. Shallow marine bioclastic deposits are thicker at Site 956 than at Site 955, suggesting that these sediments were derived from the southern Canary Islands.

Although age constraints cannot be precisely defined at these sites, the general trend of sedimentation is consistent with sealevel variations being responsible for transport of the continentally derived turbidites. Quartz-rich turbidite deposits composed of well-rounded, very fine-grained sand were derived from Saharan eolian sands that migrated onto the subaerially exposed continental shelf and were shed into the deep marine environment during falls in sea level. Shallow marine bioclastic and foraminifer-rich turbidites also correspond to periods of sea-level fluctuations. However, the presence of volcaniclastic material within several bioclastic deposits indicates volcanic activity may have been responsible for some of their deposition.

Large-scale submarine slumping appears to be more active during periods of intensified bottom currents and upwelling. Additionally, slumping was more frequent at Site 956 on the lower flank of Gran Canaria. Slump block ages are only slightly older than those of the surrounding sediment, and mass movement may have resulted from increased sedimentation and/or earthquakes associated with Canary Islands volcanism.
\end{abstract}

\section{INTRODUCTION}

Two of the seven sites drilled during Ocean Drilling Program (ODP) Leg 157 are located south of Gran Canaria (Sites 955 and 956; Figs. 1, 2) off northwestern Africa. The sedimentary succession recovered at Site 955 is $599 \mathrm{~m}$ thick and is $704 \mathrm{~m}$ thick at Site 956. The sediments recovered at both sites ranges in age from Pleistocene to middle Miocene. Sixty-five volcaniclastic and 336 nonvolcaniclastic silt and sand turbidite deposits were recovered at Site 955, whereas 272 volcaniclastic and 401 nonvolcaniclastic turbidites were recovered at Site 956.

The geology and climate of northern Africa controls the amount and type of terrigenous input to the deep marine sediments of the eastern Atlantic. Sedimentologic and provenance variations of coarse-grained units in the deep marine environment therefore provide an important tool in interpreting the depositional processes and their possible relationship to sea-level changes on the adjacent continental margin (e.g., Berger and von Rad, 1972; Sarnthein and Diester-Haas, 1977; Sarnthein, 1978; Arthur et al., 1979; Chamley and Diester-Haas, 1979; Sarnthein et al., 1982; Auffret et al., 1984; Faugeres et al., 1989; Tiedemann et al., 1989; Tiedemann et al., 1994).

During a sea-level fall, such as during a glacial period, much of the continental shelf is exposed, allowing eolian sands from the Sahara Desert to migrate farther seaward to the new shelf edge (Sarnthein and Diester-Haass, 1977; Sarnthein, 1978; Chamley and Diester-Haass, 1979; Auffret et al., 1984; Faugeres et al., 1989; Tiedemann et al., 1989). As a result, during sea-level lowstands or as sea levels are rising or falling, there should be an increase in the fre-

'Weaver, P.P.E., Schmincke, H.-U., Firth, J.V., and Duffield, W. (Eds.), 1998. Proc. $O D P$, Sci. Results, 157: College Station, TX (Ocean Drilling Program).

${ }^{2}$ Geological Sciences, University of Nevada, Reno, NV 89557, U.S.A. patrick@cs.unr.edu (Present address: Midas Joint Venture, Star Route Midas, via Golconda, NV 89414, U.S.A.). quency of quartz-rich turbidites being shed off the continental shelf into the deep marine environment. Additionally, there will be an increase in the amount of shallow marine detritus, such as bioclastic material and glauconite, transported into the deep marine environment. Glauconite would be eroded from older, exposed shelf sediments during a sea-level lowstand. Exposure and erosion of sediment containing shallow marine organisms would more likely be shed into the deep marine environment during a sea-level lowstand.

When sea levels are relatively high, such as during an interglacial period, coarse-grained sediment is trapped on the continental shelf. During such periods, very little coarse-grained material would be deposited in the deep marine environment, except by longshore currents traversing the shelf or where the continental shelf is bisected by a submarine canyon (not the case adjacent to Sites 955 and 956).

This paper uses the stratigraphy and relative ages of turbidites and slump deposits to provide a history of mass movement off this part of the African continent from the Pleistocene to middle Miocene. Turbidite and slump deposition is placed within a time-stratigraphic context to explore the response of deep marine deposition to sea-level fluctuations that correlate with climatic changes in northwestern Africa. Lithofacies analyses, within timing defined by biostratigraphic age control (data from Shipboard Scientific Party, 1995c, 1995d), are used to interpret time variations in the depositional processes south of the Canary Islands and relations to periods of volcanism and changes in sea level (e.g., Haq et al., 1987). Additionally, these sediments are, in part, the proximal equivalents to deposits in the Madeira Abyssal Plain (Weaver and Kuijpers, 1983; Weaver et al., 1986; Rothwell et al., Chap. 28; Weaver et al., Chap. 38; both this volume) and will help to correlate depositional cycles between the continent and abyssal plain.

\section{METHODS}

Onboard core analyses provided data on the distribution, thickness, and major detrital components of turbidite sands and silts for

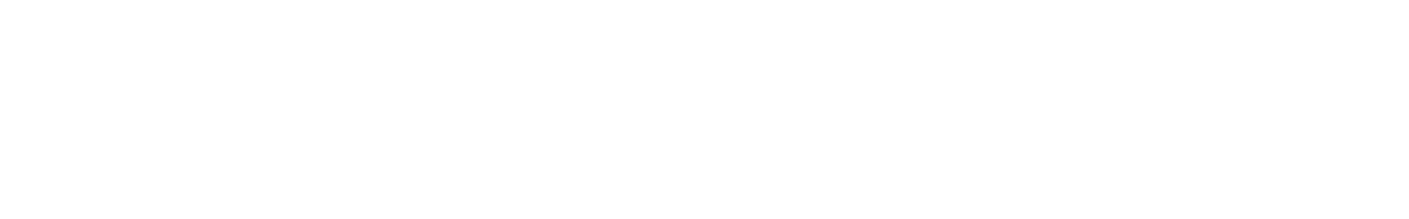




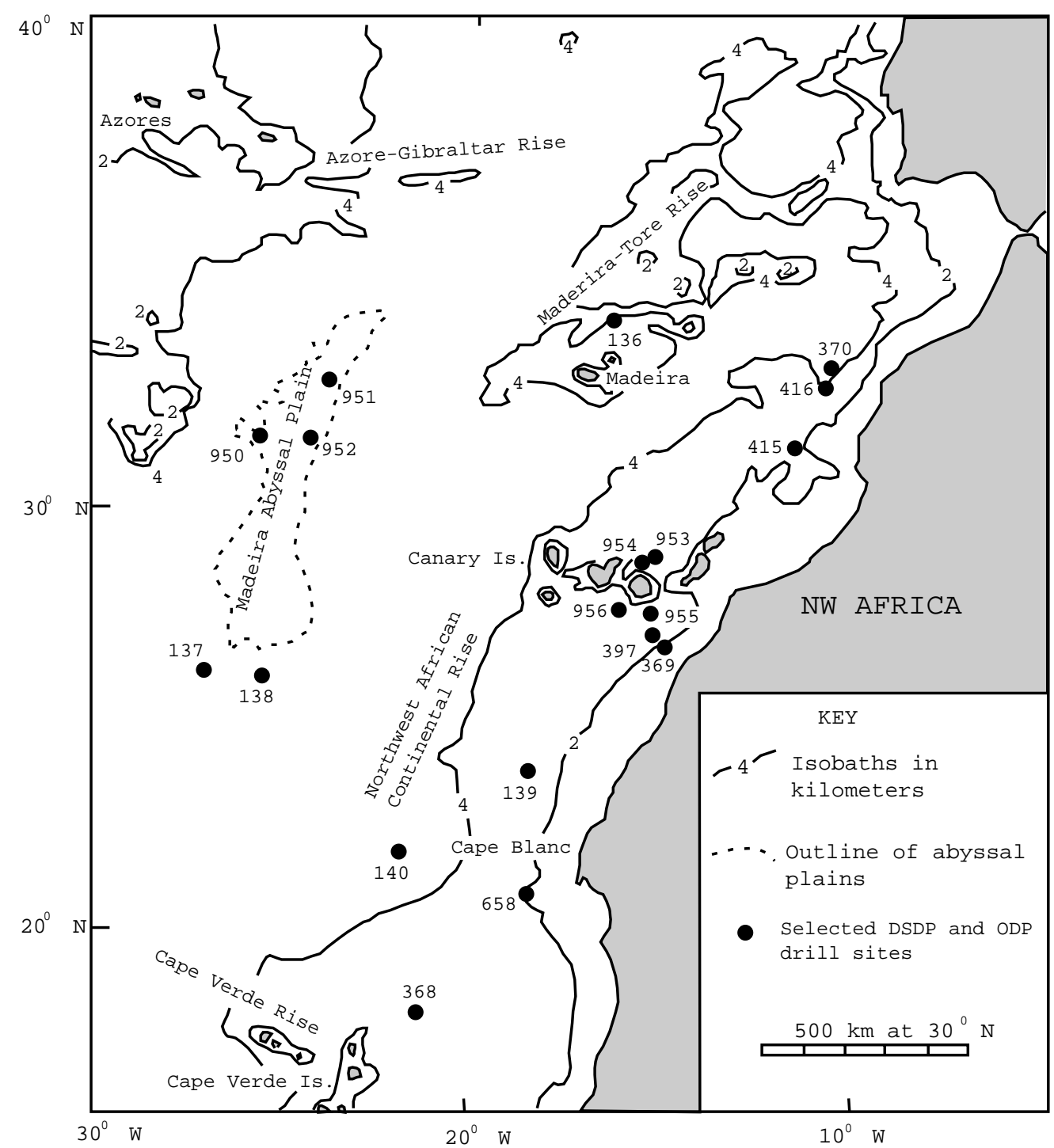

Figure 1. Regional setting of the Canary Islands and Madeira Abyssal Plain. Modified from Weaver et al. (1986).

core collected at Sites 955 and 956. Biostratigraphic data (Schmincke, Weaver, Firth, et al., 1995) for each site are used to place these turbidite deposits within a time-stratigraphic framework (Table 1). Details of the biostratigraphic time scale used are described by the Shipboard Scientific Party (1995a, p. 31). In Table 1, the depth and age ranges for Sites 955 and 956 have been interpreted from the datum levels used to calculate sediment accumulation rates (see Shipboard Scientific Party, 1995c, p. 479; 1995d, p. 543). In some cases, the biostratigraphic age limits are poorly constrained, ranging over several meters of core. Possible errors in the placement of these limits (by this author) are estimated and shown in Table 1, where a positive value indicates that the maximum depth limit may be overcalculated by the number of meters shown. A negative value indicates that the maximum depth may be shallower than indicated in Table 1. Correlation of volcaniclastic layers within the core with distinctive volcanic deposits on Gran Canaria (K/Ar age data from McDougall and Schmincke, 1977; Schmincke, 1982; H.-U. Schmincke, pers. comm., 1994), were used to refine the biostratigraphic age controls (i.e., ash layers at Site 955, 541.6 m, 13.63 Ma; 546 m, 13.71 $\mathrm{Ma} ; 565 \mathrm{~m}, 14 \mathrm{Ma}$; and at Site 956 detritus P1-ignimbrite at $564 \mathrm{~m}$, 14 Ma; Shipboard Scientific Party, 1995c, 1995d). Although the lo- cation and probable timing of slump deposits are used to determine the sedimentologic history at these sites, turbidite sand layers and the few biostratigraphic ages that occur within slumped intervals are not used in this study.

Samples were sieved through a set of $700-$ to $<63-\mu \mathrm{m}$ mesh sieves for 15 min using a "Roto-tap" machine. The dry weight of each sieved size was measured, and the fraction of the total weight of sand, silt, and mud was calculated (Appendix A).

Petrographic analyses of 67 sand-sized samples were conducted using the Gazzi-Dickinson point-counting method described by Ingersoll et al. (1984). Three hundred framework grains were counted per thin section. Thin sections were stained for both plagioclase and potassium feldspar. The following grains were identified: quartz (monocrystalline and polycrystalline), plagioclase, potassium feldspar, volcanic lithic fragments, benthic foraminifers, planktonic foraminifers, bioclastic (shell fragments), rounded carbonate grains, plant fragments, pyroxene, amphibole, altered (generally chloritic) mafic minerals, glauconite, biotite, pyrite, dolomite, zircon, zeolite, and rare garnet (Appendix B).

Volcanic lithic fragments are texturally subdivided into vitric (Lvv), felsitic (Lvf), microlitic (Lvm), and lathwork (Lvl); the no- 


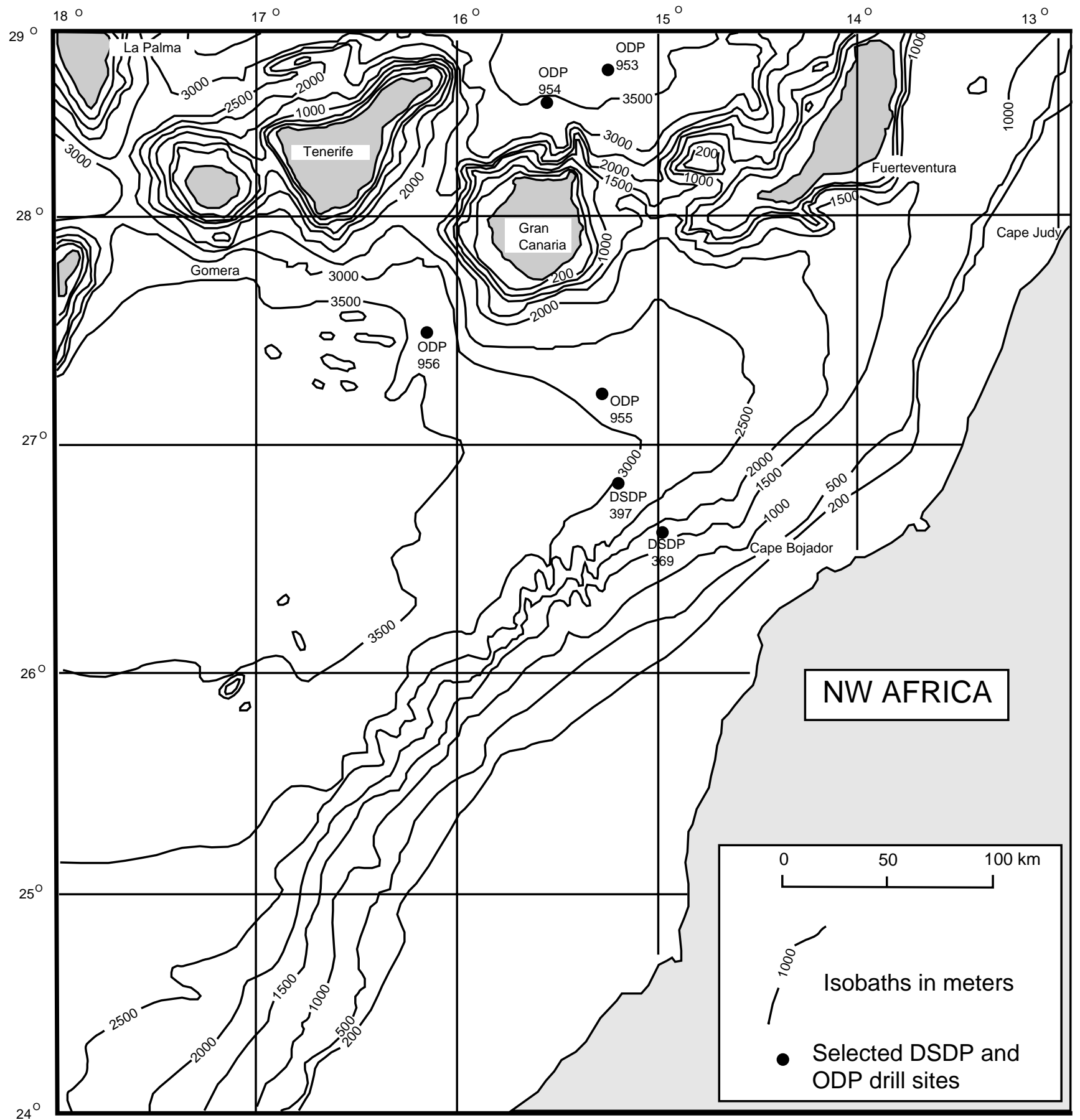

Figure 2. Locations of selected ODP and DSDP sites and bathymetry adjacent to the Canary Islands and northwestern Africa. Simplified from Ranke et al. (1982).

menclature is adapted from Dickinson (1970). Bioclastic fragments include rounded to angular shell fragments of bivalves, scaphopods, coral, echinoids, pteropods, sponges, bryozoa, rare barnacles, and unidentifiable foraminifers and calcareous tests. Rounded carbonate grains consist of both micritic and sparry calcite and rare ooids.

Parameters used to define petrographic suites include total quartzfeldspar-lithic grains (QFL) where "Q" is the percent quartzose grains including rare chert, " $F$ " is the percent feldspar, and " $\mathrm{L}$ " is the percent lithic grains; including volcaniclastic, bioclastic, and rounded carbonate grains and foraminifer tests. The following ratios are used within the text to help define continental shelf and volcanic island source areas: total volcanic lithic grains/total lithics (Lv/L), and glauconite/total dense minerals (G/DM), which include pyroxene, amphibole, biotite, and altered mafic grains (Table 2).

Individual turbidite layers have been grouped into six categories: volcaniclastic, quartz-rich, bioclastic-rich, foraminifer-rich, mixed, and miscellaneous (Table 1). The number of each type of turbidite per depth and age range is shown in Table 1 . The volcaniclastic group 
Table 1. Estimated depths and age ranges and number of turbidites per age interval.

\begin{tabular}{|c|c|c|c|c|c|c|c|c|c|c|}
\hline \multicolumn{2}{|c|}{ Depth (m) } & \multirow{2}{*}{$\begin{array}{l}\text { Possible } \\
\text { error }(\mathrm{m})\end{array}$} & \multicolumn{2}{|c|}{ Age (Ma) } & \multicolumn{6}{|c|}{ Number of turbidites } \\
\hline Minimum & Maximum & & Minimum & Maximum & Volcanic & Quartz & Bioclastic & Foraminifers & Mixed & Misc. \\
\hline \multicolumn{11}{|l|}{ Site 955} \\
\hline 0 & 27.3 & +5.38 & 0 & 0.26 & 4 & 1 & 3 & 2 & 1 & 3 \\
\hline 27.3 & 29.3 & +2.00 & 0.26 & 0.46 & 0 & 0 & 0 & 0 & 0 & 1 \\
\hline 29.3 & 56.28 & +1.12 & 0.46 & 0.83 & 0 & 0 & 6 & 2 & 0 & 0 \\
\hline 56.28 & 74.92 & +1.59 & 0.83 & 1.03 & 0 & 2 & 0 & 6 & 1 & 0 \\
\hline 74.92 & 82.54 & +7.62 & 1.03 & 1.24 & 0 & 5 & 0 & 0 & 0 & 0 \\
\hline 82.54 & 93.73 & +0.50 & 1.24 & 1.46 & 0 & 9 & 0 & 0 & 0 & 10 \\
\hline 93.73 & 102.8 & 0 & 1.46 & 1.6 & 0 & 0 & 0 & 0 & 0 & 0 \\
\hline 102.8 & 103.07 & 0 & 1.6 & 2.37 & 0 & 0 & 0 & 0 & 0 & 0 \\
\hline 103.07 & 114.86 & 0 & 2.37 & 2.44 & 0 & 5 & 0 & 1 & 0 & 2 \\
\hline 114.86 & 122.19 & 0 & 2.44 & 2.76 & 0 & 6 & 0 & 0 & 0 & 0 \\
\hline 122.19 & 208.99 & 0 & 2.76 & 3.77 & 0 & 73 & 2 & 1 & 0 & 5 \\
\hline 208.99 & 235.9 & 0 & 3.77 & 4.39 & 0 & 1 & 0 & 0 & 0 & 0 \\
\hline 235.9 & 243.58 & 0 & 4.39 & 4.63 & 0 & 0 & 0 & 0 & 0 & 0 \\
\hline 243.58 & 262.87 & +3.25 & 4.63 & 5.38 & 0 & 0 & 0 & 0 & 0 & 0 \\
\hline 262.87 & 272.56 & +9.70 & 5.38 & 5.4 & 0 & 0 & 0 & 1 & 0 & 0 \\
\hline 272.56 & 291.09 & +8.87 & 5.4 & 6.8 & 0 & 0 & 0 & 0 & 0 & 0 \\
\hline 291.09 & 310.78 & 0 & 6.8 & 7.3 & 0 & 3 & 0 & 0 & 0 & 0 \\
\hline 310.78 & 317.6 & 0 & 7.3 & 7.6 & 0 & 2 & 0 & 2 & 0 & 0 \\
\hline 317.6 & 344.9 & +4.50 & 7.6 & 8.4 & 0 & 8 & 0 & 3 & 4 & 5 \\
\hline 344.9 & 370 & +6.00 & 8.4 & 8.8 & 0 & 21 & 1 & 2 & 3 & 5 \\
\hline 370 & 370.1 & -3.60 & 8.8 & 9.4 & 0 & 0 & 0 & 0 & 0 & 0 \\
\hline 370.1 & 415.18 & 0 & 9.4 & 9.99 & 0 & 22 & 3 & 6 & 14 & 8 \\
\hline 415.18 & 445.84 & +1.05 & 9.99 & 10.8 & 1 & 5 & 0 & 3 & 19 & 2 \\
\hline 445.84 & 461.54 & +7.48 & 10.8 & 11.6 & 4 & 0 & 0 & 0 & 7 & 1 \\
\hline 461.54 & 464 & 0 & 11.6 & 11.7 & 0 & 0 & 0 & 0 & 0 & 0 \\
\hline 464 & 487.55 & 0 & 11.7 & 12.7 & 7 & 5 & 0 & 1 & 2 & 6 \\
\hline 487.55 & 526.6 & +8.86 & 12.7 & 13.6 & 12 & 1 & 0 & 1 & 3 & 1 \\
\hline 526.6 & 541.6 & 0 & 13.6 & 13.63 & 5 & 0 & 0 & 0 & 0 & 0 \\
\hline 541.6 & 546 & 0 & 13.63 & 13.71 & 10 & 0 & 0 & 0 & 0 & 0 \\
\hline 546 & 565 & 0 & 13.71 & 14 & 14 & 0 & 0 & 0 & 0 & 0 \\
\hline 565 & 574.25 & 0 & 14 & 15.1 & 5 & 7 & 0 & 0 & 0 & 0 \\
\hline 574.25 & 595.06 & +0.16 & 15.1 & 15.8 & 3 & 5 & 0 & 0 & 1 & 6 \\
\hline 595.06 & 595.44 & & $>15.8$ & & 1 & 0 & 0 & 0 & 0 & 0 \\
\hline \multicolumn{11}{|l|}{ Site 956} \\
\hline 0 & 9.63 & +3.57 & 0 & 0.26 & 0 & 0 & 4 & 0 & 0 & 3 \\
\hline 9.63 & 22.18 & 0 & 0.26 & 0.46 & 0 & 0 & 7 & 0 & 0 & 6 \\
\hline 22.18 & 63.15 & +3.14 & 0.46 & 1.92 & 30 & 0 & 1 & 3 & 8 & 12 \\
\hline 63.15 & 70.09 & 0 & 1.92 & 2.19 & 9 & 0 & 0 & 0 & 1 & 0 \\
\hline 70.09 & 82.14 & 0 & 2.19 & 2.37 & 24 & 0 & 0 & 0 & 4 & 0 \\
\hline 82.14 & 82.15 & 0 & 2.37 & 2.44 & 0 & 0 & 0 & 0 & 0 & 0 \\
\hline 82.15 & 84.63 & 0 & 2.44 & 2.61 & 2 & 0 & 0 & 0 & 0 & 0 \\
\hline 84.63 & 157.59 & +9.84 & 2.61 & 3.15 & 3 & 50 & 0 & 6 & 43 & 11 \\
\hline 157.59 & 211.25 & 0 & 3.15 & 4.39 & 11 & 14 & 0 & 2 & 0 & 1 \\
\hline 211.25 & 219.7 & 0 & 4.39 & 4.63 & 0 & 2 & 0 & 1 & 0 & 1 \\
\hline 219.7 & 250.98 & 0 & 4.63 & 5.4 & 0 & 4 & 0 & 0 & 0 & 0 \\
\hline 250.98 & 258.42 & 0 & 5.4 & 5.56 & 0 & 2 & 0 & 5 & 0 & 0 \\
\hline 258.42 & 315.77 & +7.76 & 5.56 & 6.5 & 0 & 6 & 0 & 5 & 2 & 3 \\
\hline 315.77 & 344.75 & 0 & 6.5 & 6.8 & 0 & 3 & 0 & 0 & 0 & 7 \\
\hline 344.75 & 362.6 & +8.29 & 6.8 & 7.3 & 1 & 12 & 0 & 1 & 0 & 0 \\
\hline 362.6 & 399.07 & 0 & 7.3 & 8.8 & 12 & 12 & 0 & 0 & 3 & 4 \\
\hline 399.07 & 399.07 & 0 & 8.8 & 9.4 & 0 & 0 & 0 & 0 & 0 & 0 \\
\hline 399.07 & 446.3 & 0 & 9.4 & 9.99 & 25 & 4 & 0 & 2 & 14 & 15 \\
\hline 446.3 & 446.3 & 0 & 9.99 & 10.8 & 0 & 0 & 0 & 0 & 0 & 0 \\
\hline 446.3 & 459.57 & +2.08 & 10.8 & 11.6 & 8 & 0 & 0 & 0 & 0 & 0 \\
\hline 459.57 & 466.21 & +0.20 & 11.6 & 13.67 & 8 & 0 & 0 & 1 & 0 & 0 \\
\hline 466.21 & 564 & 0 & 13.67 & 14 & 103 & 0 & 0 & 3 & 1 & 0 \\
\hline 564 & 657.82 & 0 & 14 & 14.6 & 36 & 0 & 0 & 7 & 3 & 2 \\
\hline
\end{tabular}

Notes: Possible error numbers indicate uncertainty in biostratigraphic age limits (from Shipboard Scientific Party 1995c, p. 479; 1995d, p. 543). Positive values = possible overestimation of the maximum depth limit, and negative values $=$ a possible underestimation of the lower depth range. Turbidite class abbreviations: volcanic $=$ volcaniclastic, quartz $=$ quartz-rich, bioclastic $=$ bioclastic-rich, foraminifers $=$ foraminifer-rich, mixed $=$ mixed component turbidites, and misc. $=$ miscellaneous turbidites .

consists of volcanic lithic fragments, feldspar, and mafic minerals (e.g., pyroxene and amphibole). The quartz-rich turbidites contain mostly monocrystalline quartz. The bioclastic group consists of shell fragments of shallow marine organisms, whereas the foraminifer-rich turbidites are predominately composed of various mixtures of benthic and planktonic foraminifers. The mixed group includes turbidites consisting of various mixtures of quartz, feldspar, volcanic lithics, foraminifers, glauconite, and mafic minerals of volcanic origin. The miscellaneous category represents mostly silt-sized turbidites, most of which are calcareous.

\section{RESULTS}

\section{Sedimentation}

The Pleistocene to middle Miocene sedimentary succession recovered at Sites 955 and 956 consist of abundant hemipelagic clays with minor interbeds of finely laminated to thinly bedded and rare, very thickly bedded volcaniclastic, siliciclastic, and bioclastic turbidite deposits. The volcaniclastic components of these silt and sand turbidites relate to periods of known volcanism in the Canary Islands (McDougall and Schmincke, 1977; Schmincke and von Rad, 1979; Schmincke, 1982; Staudigel and Schmincke, 1984; van den Bogaard and Schmincke, Chap 11, this volume). The nonvolcaniclastic units are composed of various mixtures of quartz, glauconite, shallow marine bioclastic, and foraminifer sand and silt derived mostly from the continental margin of northwest Africa.

At Site 955, 161 quartz-rich turbidites were identified, whereas 108 were identified at Site 956 . These data indicate that continentally derived sediment is slightly more abundant at Site 955 (Fig. 3) than at Site 956 (Fig. 4), and is a result of their locations with respect to the sediment dispersal patterns off northwestern Africa. Site 955 is located on the northern flank of a southwest-trending trough that re- 
Table 2. Summary of petrographic analyses from selected samples from Sites 955 and 956.

\begin{tabular}{|c|c|c|c|c|c|c|c|c|c|c|c|}
\hline $\begin{array}{l}\text { Core, section, } \\
\text { interval }(\mathrm{cm})\end{array}$ & $\mathrm{Q} / \mathrm{QFL}$ & F/QFL & $\mathrm{L} / \mathrm{QFL}$ & $\mathrm{P} / \mathrm{F}$ & $\mathrm{K} / \mathrm{F}$ & $\mathrm{Lvv} / \mathrm{Lv}$ & $\mathrm{Lvf} / \mathrm{Lv}$ & $\mathrm{Lvm} / \mathrm{Lv}$ & $\mathrm{Lvl} / \mathrm{Lv}$ & $\mathrm{Lv} / \mathrm{L}$ & G/DM \\
\hline \multicolumn{12}{|l|}{$157-955 \mathrm{~A}-$} \\
\hline $9 \mathrm{H}-2,12-14$ & 0.53 & 0.18 & 0.29 & 0.43 & 0.57 & 0.24 & 0.71 & 0.06 & 0.00 & 0.23 & 0.00 \\
\hline $10 \mathrm{H}-1,120-122$ & 0.01 & 0.02 & 0.98 & 0.50 & 0.50 & 1.00 & 0.00 & 0.00 & 0.00 & 0.97 & 0.00 \\
\hline $11 \mathrm{H}-4,24-26$ & 0.40 & 0.12 & 0.48 & 0.70 & 0.30 & 0.40 & 0.60 & 0.00 & 0.00 & 0.04 & 0.57 \\
\hline $12 \mathrm{H}-3,109-111$ & 0.76 & 0.10 & 0.15 & 0.82 & 0.18 & - & - & - & - & 0.00 & 0.00 \\
\hline $13 \mathrm{H}-5,71-73$ & 0.60 & 0.10 & 0.30 & 0.71 & 0.29 & 1.00 & 0.00 & 0.00 & 0.00 & 0.17 & 0.50 \\
\hline $14 \mathrm{H}-6,69-71$ & 0.78 & 0.10 & 0.12 & 0.73 & 0.27 & 0.00 & 0.00 & 0.00 & 1.00 & 0.86 & 0.00 \\
\hline $17 \mathrm{H}-2,125-127$ & 0.67 & 0.20 & 0.13 & 0.78 & 0.22 & 0.24 & 0.65 & 0.12 & 0.00 & 0.50 & 0.43 \\
\hline $17 \mathrm{H}-4,90-92$ & 0.70 & 0.15 & 0.16 & 0.71 & 0.29 & 0.27 & 0.73 & 0.00 & 0.00 & 0.34 & 0.43 \\
\hline $18 \mathrm{H}-2,117-119$ & 0.68 & 0.15 & 0.17 & 0.66 & 0.34 & 0.75 & 0.25 & 0.00 & 0.00 & 0.19 & 0.42 \\
\hline $18 \mathrm{H}-3,41-43$ & 0.62 & 0.21 & 0.18 & 0.63 & 0.37 & 0.00 & 0.77 & 0.23 & 0.00 & 0.27 & 0.17 \\
\hline $19 X-4,34-36$ & 0.88 & 0.07 & 0.05 & 0.70 & 0.30 & 0.00 & 0.00 & 1.00 & 0.00 & 0.15 & 0.00 \\
\hline $20 X-2,145-147$ & 0.69 & 0.22 & 0.09 & 0.49 & 0.51 & 0.00 & 1.00 & 0.00 & 0.00 & 0.15 & 0.00 \\
\hline $20 X-3,111-113$ & 0.68 & 0.17 & 0.15 & 0.57 & 0.43 & 0.00 & 0.86 & 0.14 & 0.00 & 0.17 & 0.00 \\
\hline $21 X-2,76-78$ & 0.73 & 0.15 & 0.13 & 0.43 & 0.57 & 0.00 & 0.88 & 0.13 & 0.00 & 0.44 & 0.22 \\
\hline $22 X-1,143-145$ & 0.77 & 0.13 & 0.10 & 0.41 & 0.59 & 0.00 & 0.64 & 0.27 & 0.09 & 0.38 & 1.00 \\
\hline $22 X-4,113-115$ & 0.84 & 0.07 & 0.08 & 0.81 & 0.19 & - & - & - & - & 0.00 & 0.67 \\
\hline $22 X-5,30-32$ & 0.79 & 0.11 & 0.10 & 0.72 & 0.28 & 0.67 & 0.33 & 0.00 & 0.00 & 0.31 & 0.50 \\
\hline $33 X-6,84-86$ & 0.84 & 0.15 & 0.02 & 0.63 & 0.37 & 0.00 & 0.00 & 1.00 & 0.00 & 0.80 & 0.00 \\
\hline $33 X-6,111-113$ & 0.84 & 0.12 & 0.04 & 0.54 & 0.46 & 0.29 & 0.43 & 0.29 & 0.00 & 0.64 & 0.00 \\
\hline $34 X-1,85-87$ & 0.76 & 0.14 & 0.10 & 0.59 & 0.41 & 0.20 & 0.60 & 0.00 & 0.20 & 0.19 & 0.33 \\
\hline $36 X-1,85-87$ & 0.76 & 0.07 & 0.17 & 0.61 & 0.39 & 0.00 & 1.00 & 0.00 & 0.00 & 0.11 & 0.33 \\
\hline $37 X-3,146-148$ & 0.50 & 0.10 & 0.41 & 0.76 & 0.24 & 0.67 & 0.33 & 0.00 & 0.00 & 0.07 & 0.80 \\
\hline $37 X-6,81-83$ & 0.70 & 0.14 & 0.16 & 0.69 & 0.31 & 0.00 & 1.00 & 0.00 & 0.00 & 0.20 & 0.11 \\
\hline $38 X-5,90-92$ & 0.82 & 0.14 & 0.04 & 0.85 & 0.15 & 0.00 & 1.00 & 0.00 & 0.00 & 0.73 & 0.19 \\
\hline $40 X-2,67-69$ & 0.85 & 0.12 & 0.03 & 0.73 & 0.27 & 0.00 & 0.00 & 0.00 & 1.00 & 0.50 & 0.58 \\
\hline $41 X-1,103-105$ & 0.79 & 0.14 & 0.06 & 0.59 & 0.41 & 0.00 & 0.25 & 0.75 & 0.00 & 0.24 & 0.68 \\
\hline $41 X-3,34-36$ & 0.70 & 0.16 & 0.14 & 0.84 & 0.16 & 0.17 & 0.17 & 0.00 & 0.67 & 0.31 & 0.47 \\
\hline $41 X-3,72-74$ & 0.65 & 0.13 & 0.23 & 0.63 & 0.37 & 0.31 & 0.06 & 0.16 & 0.47 & 0.52 & 0.44 \\
\hline $41 X-3,137-139$ & 0.73 & 0.14 & 0.12 & 0.73 & 0.28 & 0.00 & 0.23 & 0.77 & 0.00 & 0.38 & 0.13 \\
\hline $41 X-5,60-62$ & 0.81 & 0.14 & 0.06 & 0.64 & 0.36 & 0.38 & 0.25 & 0.38 & 0.00 & 0.50 & 0.54 \\
\hline $42 X-3,114-116$ & 0.67 & 0.22 & 0.11 & 0.85 & 0.15 & 0.50 & 0.00 & 0.35 & 0.15 & 0.69 & 0.46 \\
\hline $42 X-4,85-87$ & 0.01 & 0.28 & 0.71 & 0.88 & 0.12 & 0.72 & 0.23 & 0.05 & 0.00 & 0.95 & 0.00 \\
\hline $43 X-1,67-69$ & 0.00 & 0.14 & 0.86 & 0.60 & 0.40 & 0.73 & 0.23 & 0.04 & 0.00 & 0.47 & - \\
\hline $43 \mathrm{X}-\mathrm{CC}, 28-30$ & 0.72 & 0.16 & 0.13 & 0.64 & 0.36 & 0.42 & 0.37 & 0.21 & 0.00 & 0.53 & 0.44 \\
\hline $44 X-4,34-36$ & 0.70 & 0.22 & 0.07 & 0.58 & 0.42 & 0.09 & 0.45 & 0.45 & 0.00 & 0.55 & 0.65 \\
\hline $44 X-6,79-81$ & 0.66 & 0.15 & 0.19 & 0.66 & 0.34 & 0.00 & 0.91 & 0.09 & 0.00 & 0.21 & 0.80 \\
\hline $45 X-1,64-66$ & 0.00 & 0.40 & 0.60 & 0.17 & 0.83 & 0.50 & 0.48 & 0.02 & 0.00 & 0.64 & 0.00 \\
\hline $45 X-1,135-137$ & 0.78 & 0.13 & 0.09 & 0.74 & 0.26 & 0.43 & 0.57 & 0.00 & 0.00 & 0.28 & 0.67 \\
\hline $47 X-5,66-68$ & 0.79 & 0.16 & 0.06 & 0.56 & 0.44 & 0.00 & 0.71 & 0.14 & 0.14 & 0.44 & 0.64 \\
\hline $48 X-1,69-71$ & 0.89 & 0.04 & 0.08 & 0.78 & 0.22 & 0.00 & 0.50 & 0.00 & 0.50 & 0.11 & 0.85 \\
\hline $50 X-1,106-108$ & 0.69 & 0.16 & 0.14 & 0.60 & 0.40 & 1.00 & 0.00 & 0.00 & 0.00 & 0.14 & 0.83 \\
\hline $51 X-2,35-37$ & 0.89 & 0.02 & 0.08 & 0.67 & 0.33 & 0.75 & 0.25 & 0.00 & 0.00 & 0.18 & 0.60 \\
\hline $60 X-4,50-52$ & 0.80 & 0.10 & 0.10 & 0.63 & 0.37 & 0.20 & 0.00 & 0.40 & 0.40 & 0.19 & 0.29 \\
\hline $60 X-4,114-116$ & 0.82 & 0.10 & 0.08 & 0.62 & 0.38 & 0.83 & 0.17 & 0.00 & 0.00 & 0.29 & 0.50 \\
\hline $62 X-4,19-21$ & 0.85 & 0.07 & 0.08 & 0.65 & 0.35 & 0.92 & 0.08 & 0.00 & 0.00 & 0.50 & 1.00 \\
\hline \multicolumn{12}{|l|}{$157-956 \mathrm{~A}-$} \\
\hline $10 \mathrm{H}-6,101-103$ & 0.00 & 0.20 & 0.80 & 0.88 & 0.12 & 0.40 & 0.00 & 0.02 & 0.58 & 0.74 & 0.12 \\
\hline $11 \mathrm{H}-5,7-9$ & 0.48 & 0.18 & 0.34 & 0.84 & 0.16 & 0.00 & 0.00 & 0.00 & 1.00 & 0.03 & 0.22 \\
\hline $11 \mathrm{H}-6,30-32$ & 0.45 & 0.08 & 0.47 & 0.94 & 0.06 & 1.00 & 0.00 & 0.00 & 0.00 & 0.01 & 0.67 \\
\hline $14 \mathrm{H}-3,55-57$ & 0.56 & 0.15 & 0.29 & 0.81 & 0.19 & - & - & - & - & 0.00 & 0.30 \\
\hline $14 \mathrm{H}-5,33-35$ & 0.54 & 0.14 & 0.32 & 0.78 & 0.22 & 0.58 & 0.42 & 0.00 & 0.00 & 0.15 & 0.60 \\
\hline $14 \mathrm{H}-6,31-33$ & 0.00 & 0.35 & 0.64 & 1.00 & 0.00 & 0.69 & 0.00 & 0.00 & 0.31 & 1.00 & 0.00 \\
\hline $16 \mathrm{H}-2,129-131$ & 0.39 & 0.25 & 0.35 & 0.96 & 0.04 & 0.50 & 0.00 & 0.00 & 0.50 & 0.13 & 0.33 \\
\hline $16 \mathrm{H}-3,90-92$ & 0.70 & 0.16 & 0.14 & 0.83 & 0.17 & - & - & - & - & 0.00 & 0.50 \\
\hline $16 \mathrm{H}-6,47-49$ & 0.69 & 0.13 & 0.17 & 0.64 & 0.36 & - & - & - & - & 0.00 & 0.38 \\
\hline $17 \mathrm{H}-6,69-71$ & 0.00 & 0.38 & 0.62 & 1.00 & 0.00 & 0.12 & 0.00 & 0.00 & 0.88 & 0.87 & 0.00 \\
\hline $1 \mathrm{R}-3,113-115$ & 0.58 & 0.20 & 0.22 & 0.68 & 0.32 & 1.00 & 0.00 & 0.00 & 0.00 & 0.32 & 0.00 \\
\hline $6 \mathrm{R}-3,45-47$ & 0.00 & 0.02 & 0.98 & 1.00 & 0.00 & 1.00 & 0.00 & 0.00 & 0.00 & 0.95 & 0.20 \\
\hline \multicolumn{12}{|l|}{ 157-956B- } \\
\hline 7R-4, 110-112 & 0.44 & 0.17 & 0.39 & 0.64 & 0.36 & 0.80 & 0.08 & 0.00 & 0.12 & 0.67 & 0.06 \\
\hline $11 \mathrm{R}-2,118-120$ & 0.75 & 0.13 & 0.13 & 0.61 & 0.39 & 0.85 & 0.15 & 0.00 & 0.00 & 0.39 & 0.45 \\
\hline 15R-3, 33-35 & 0.11 & 0.18 & 0.70 & 0.92 & 0.08 & 0.92 & 0.00 & 0.00 & 0.08 & 0.24 & 0.00 \\
\hline $18 \mathrm{R}-2,60-62$ & 0.57 & 0.25 & 0.19 & 0.92 & 0.08 & - & - & - & - & 0.00 & 0.56 \\
\hline $21 \mathrm{R}-4,130-132$ & 0.05 & 0.28 & 0.67 & 0.91 & 0.09 & 0.72 & 0.00 & 0.00 & 0.28 & 0.54 & 0.33 \\
\hline 21R-6, 37-39 & 0.00 & 0.25 & 0.75 & 0.61 & 0.39 & 0.93 & 0.00 & 0.00 & 0.07 & 0.57 & 0.00 \\
\hline $24 \mathrm{R}-3,122-124$ & 0.76 & 0.13 & 0.11 & 0.92 & 0.08 & - & - & - & - & 0.00 & 0.55 \\
\hline $25 \mathrm{R}-1,32-34$ & 0.83 & 0.09 & 0.08 & 0.85 & 0.15 & - & - & - & - & 0.00 & 0.53 \\
\hline $27 \mathrm{R}-4,115-117$ & 0.73 & 0.15 & 0.11 & 0.73 & 0.27 & 0.92 & 0.00 & 0.00 & 0.08 & 0.43 & 0.44 \\
\hline $48 \mathrm{R}-4,28-30$ & 0.00 & 0.03 & 0.97 & 1.00 & 0.00 & 1.00 & 0.00 & 0.00 & 0.00 & 0.34 & 0.06 \\
\hline
\end{tabular}

Notes: QFL = quartz-feldspar-lithic grains where "Q" is the ratio of quartzose grains including rare chert, "F" is the ratio of feldspar, and "L" is the ratio of lithic grains (including volcaniclastic, bioclastic, and rounded carbonate grains and foraminifer tests). $\mathrm{P} / \mathrm{F}=$ ratio of plagioclase to total feldspars, $\mathrm{K} / \mathrm{F}=$ ration of potassium feldspar to total feldspars. Lvv/ $\mathrm{Lv}=$ ratio of vitric lithic fragments to total volcanic lithics, $\mathrm{Lvm} / \mathrm{Lv}=$ ratio of microlitic to total volcanic lithics, Lvl/Lv = ratio of lathwork lithics to total volcanic lithics, and Lv/ $\mathrm{L}=$ ratio of total volcanic lithic grains to total lithics. $\mathrm{G} / \mathrm{DM}=$ glauconite to total dense minerals, including pyroxene, amphibole, biotite, and altered mafic grains.

ceives sediment from both the Canary Islands and the African continent (i.e., Jacobi and Hayes, 1992; Fig. 2). Site 956 is located on the lower flank of Gran Canaria, bathymetrically higher than the trough carrying continental sediments.

Turbidite deposits consist mostly of finely laminated to thinly bedded silts and fine sands (Appendix A) interbedded within thick sequences of hemipelagic clay. However, minor medium-bedded and rare thickly bedded turbidites are present (Figs. 5, 6). Generally, turbidite beds are normally graded, having sharp, nonerosional bases, and grade upward into mud. Planar and cross-laminations are present in the medium- to thick-bedded turbidites.

Soft-sediment deformation and slump structures are common at Sites 955 and 956 (Fig. 7; Table 3). Within these slumped intervals, convolute and folded bedding, folded and deformed mud clasts, and 
Figure 3. Correlation diagram of different turbidite types and turbidite frequency per age range determined from biostratigraphic and distinctive volcaniclastic deposits at Site 955. See text for explanation of age-limit determinations and turbidite classes.

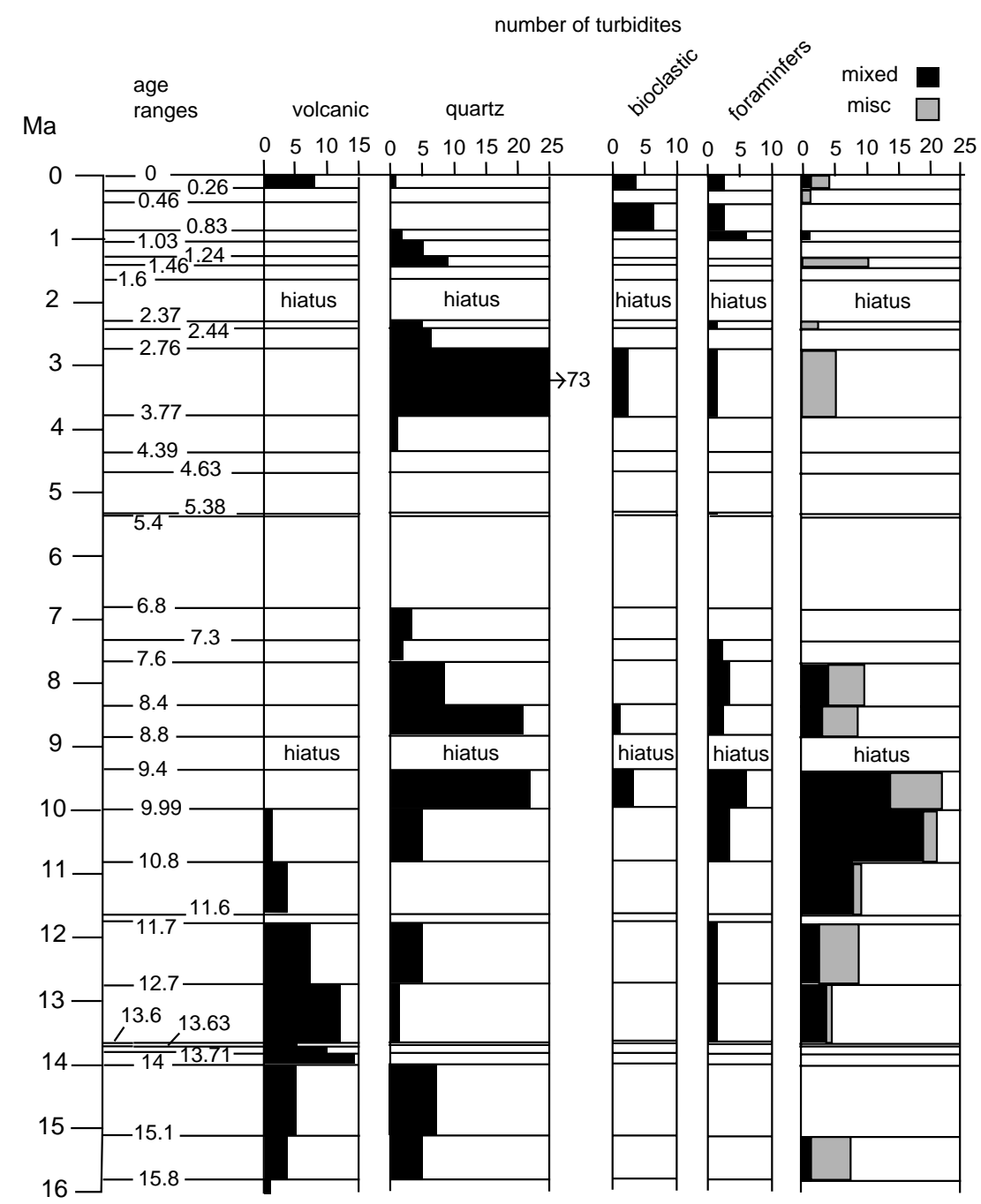

microfaults are abundant. Occasionally, isolated whole and broken bivalve shells and coral fragments are present within slump sequences of hemipelagic clay. Siliciclastic interbeds within slumped intervals are often folded and discontinuous.

Several thick- to very thick-bedded (as much as $3.63 \mathrm{~m}$ thick) bioclastic debris flow deposits are present at both sites, particularly in the Pleistocene sections (e.g., Cores 157-956A-1H and 2H; Fig. 6). These units consist of poorly sorted, coarse- to very coarse-grained, angular fragments of shallow marine organisms and volcaniclastic grains. Shell fragments include bivalves, coral, scaphopods, and echinoderm spines.

There are several hiatuses in the sedimentary succession at both sites, as well as at Site 954, north of Gran Canaria. At 103 meters below sea floor (mbsf) at Site 955, there is a hiatus between 1.6 and 2.37 Ma. A second hiatus at this site, at $370 \mathrm{mbsf}$ between 8.8 and 9.4 Ma, correlates to a hiatus at Site 956 at 399 mbsf. The same time-stratigraphic hiatus is at Site 954 (Shipboard Scientific Party, 1995b). Another hiatus is present at Site 956 between 9.99 and $10.8 \mathrm{Ma}$ at 446.3 mbsf.

\section{Provenance}

Petrographic analyses of turbidite sands from Sites 955 and 956 indicate derivation from two main provenance terranes, a recycled orogenic provenance, and an undissected volcanic provenance (Fig. 8). The provenance terranes of Dickinson et al. (1983) do not differ- entiate volcanic suites from different tectonic settings; instead, all volcanic-rich detrital sandstones are grouped into the "magmatic arc" category. Sand modes rich in volcanic lithic fragments at Sites 955 and 956 are not from arc-style volcanism but are derived from the Canary Island volcanic suites. Therefore, the magmatic arc provenance field of Dickinson et al. (1983) has been modified to the more general term of "volcanic provenance."

Most samples collected and analyzed for this study were derived from a recycled orogenic source (Fig. 8). The quartzose sands were eroded from the orogenic belts of western Africa (i.e., Berger and von Rad, 1972; Dillon and Sougy, 1974; Stets and Wurster, 1982), a source region for eolian deposits of the Sahara Desert. Mixing of continentally derived quartzose sand and detritus shed from the Canary Island volcanics occurred on the slope and rise, and is distinguished on the ternary plots by those sands with quartz percentages $<60 \%$ (Fig. 8). Because of the location of Site 956 on the flank of Gran Canaria, farther from direct continental sources and dispersal patterns, this site has experienced more mixing of volcanic material with continentally derived detritus.

Monocrystalline quartz grains are round to subangular, and some are coated with reddish iron oxide. Quartz grains are mainly nonundulose, although slightly undulose and rare sutured polycrystalline grains are present. Rounded to subrounded quartz grains are derived from eolian sands of the Sahara Desert. The subangular quartz grains are also continentally derived, but have been reworked prior to deposition on the continental rise. 


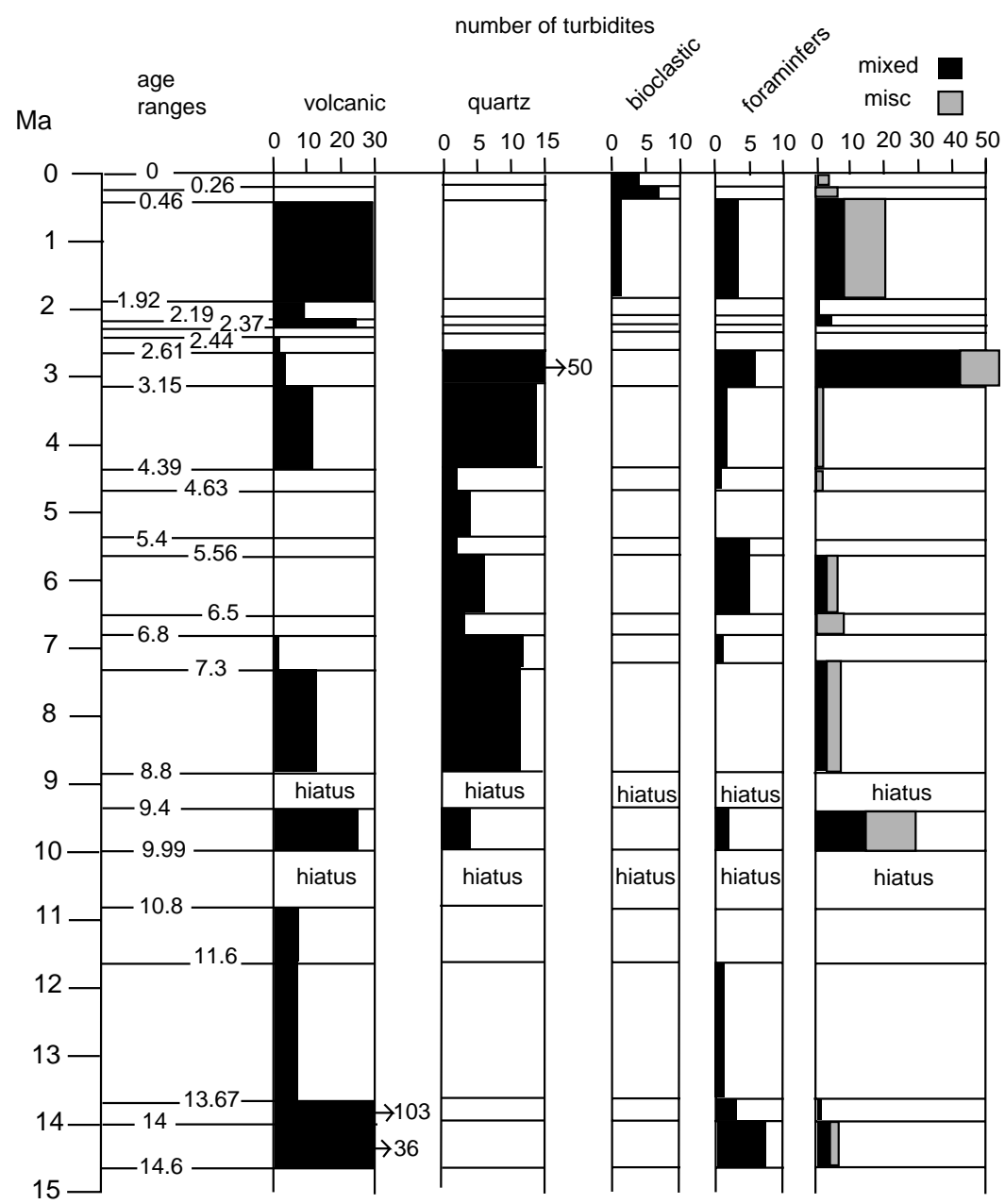

Figure 4. Correlation diagram of different turbidite types and turbidite frequency per age range determined from biostratigraphic and distinctive volcaniclastic deposits at Site 956. See text for explanation of age-limit determinations and turbidite classes.
Angular plagioclase and alkali feldspar grains are common in these sediments. Subrounded plagioclase and microcline are rare. Angular feldspars are derived from volcanic material from the Canary Islands. The subrounded grains of plagioclase indicate reworking prior to deposition, and microcline suggests a crystalline-basement provenance, therefore these grain types are interpreted as being derived from the African continent.

Most lithic fragments are volcanic or bioclastic. All volcanic lithic fragments were derived from the Canary Islands (mostly Gran Canaria). Bioclastic debris of rounded to angular shell fragments of bivalves, scaphopods, coral, echinoids, pteropods, sponges, bryozoa, and rare barnacles indicate a shallow marine origin. Site 956 has a higher frequency and thicker deposits (Fig. 6) of these turbidites and debris flows than Site 955 (Fig. 5), suggesting that carbonate rocks fringing the southern Canary Islands were the source of the bioclastic turbidites. Rounded carbonate grains of micritic and sparry calcite and rare ooids were derived from either shallow marine environments surrounding the Canary Islands or the continental shelf region.

Most of the dense minerals within the turbidites are derived from the Canary Islands volcanic suites (i.e., pyroxene, amphibole, and biotite). Euhedral and framboidal pyrite is present in nearly all intervals sampled and is diagenetic in origin. Although some of the pyrite appears to have formed in situ, some of the framboidal pyrite, common within foraminifer tests, may have been redeposited from the continental shelf or slope. Rounded glauconite grains are common in these turbidite deposits (Table 2) and indicate an origin from a continental shelf environment (e.g., Porrenga, 1967). Detrital, yellow-brown glauconite, which is present throughout the sedimentary successions at both sites, indicates oxidation of these grains. Minor zircon is present in these sediments with both euhedral and well-rounded morphologies. The euhedral zircons show no signs of prolonged transport or recycling and are probably derived from various Canary Islands volcanic units. The well-rounded zircon and rare rounded garnet grains (e.g., Sample 157-955-20X-2, 145-147 cm) suggest extensive recycling and/or transport and were derived from a continental provenance.

Biostratigraphic data from within slump blocks as well as the over- and underlying sediment provide age control on slumping events and the source of the slump blocks (Table 3). At both sites, slump block ages are only slightly older than the sediment in which they were deposited. At Site 955, slump blocks are common in the Pliocene and Quaternary sediments. Where biostratigraphic control exists, slump blocks with ages of 1.92, 3.0-3.15, 4.0, 4.39, 4.53-5.4, and 5.56 Ma were deposited within sediment ranging in age from 1.46 to $3.77 \mathrm{Ma}$. (Table 3). At Site 956, slumping was more frequent with two 1.95 m.y.-old slump blocks deposited in 0.46- to 1.92-m.y.old sediment, two 4.63-m.y.-old slump blocks occurring within sediment ranging in age from 3.15 to $4.63 \mathrm{Ma}$, and slump blocks with ages of $6.8,7.3,10.4,14.05$, and $14.16 \mathrm{Ma}$, deposited in sediment ranging from 6.5 to $6.8,6.8$ to $7.3,9.4$ to $9.99,13.67$ to 14 , and 13.67 to 14 m.y. old, respectively (Table 3 ).

\section{DEPOSITIONAL HISTORY}

The continentally derived turbidites recovered at Sites 955 and 956 provide a record of middle Miocene to Pleistocene deposition off 


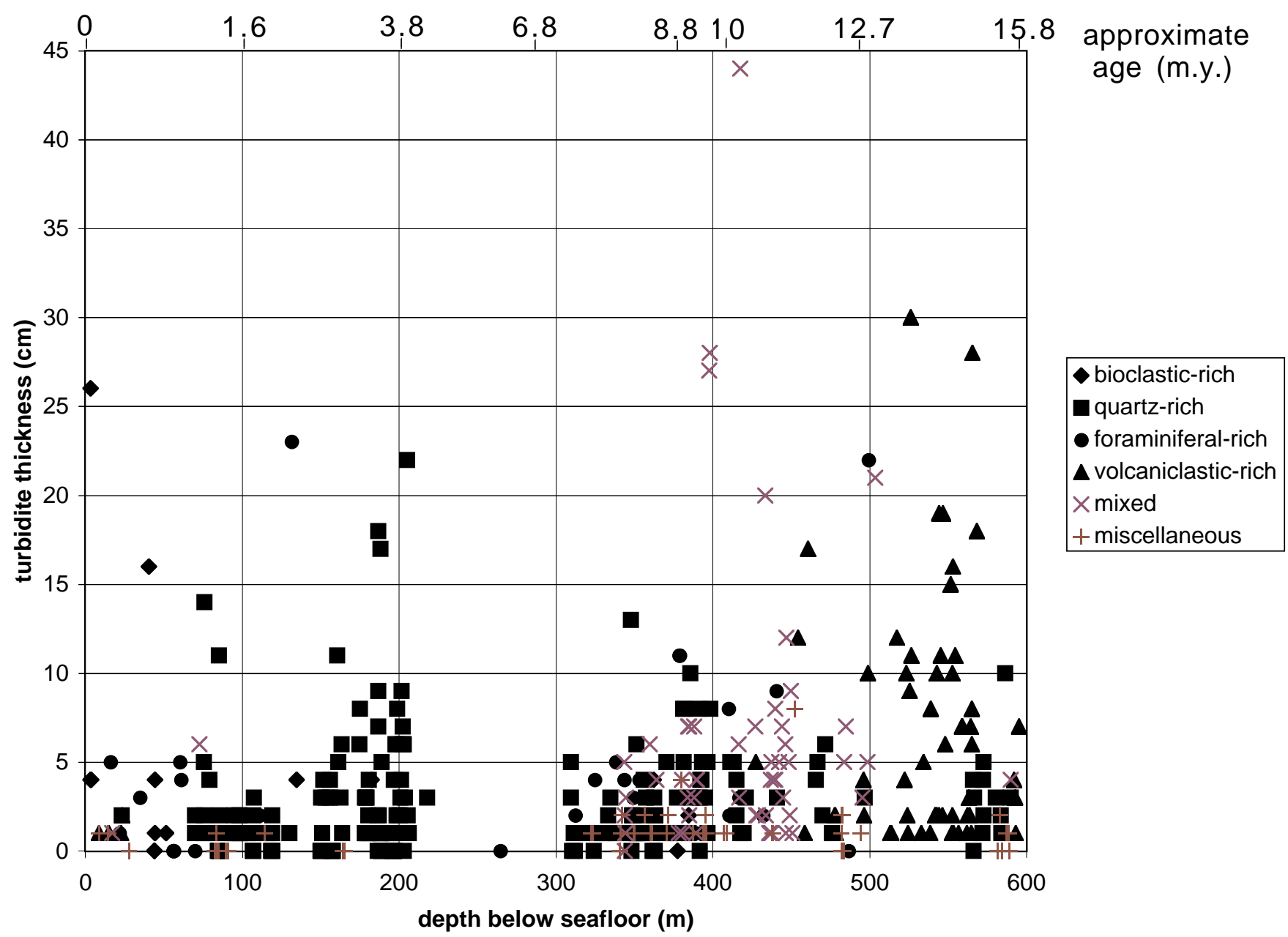

Figure 5. Plot of turbidite thickness (cm), depth below seafloor (m), and approximate age of sediment for the six major turbidite types at Site 955.

northwestern Africa and their relationship to sea-level changes. Figure 9 shows the depositional rates of the nonvolcaniclastic turbidites that were calculated from the age ranges shown in Table 1. Turbidite and slumping are calculated as the number of turbidites and slumps per 100 k.y.

\section{Middle Miocene (16.6-11.2 Ma)}

At Site 955, nonvolcaniclastic turbidite depositional rates are less than two turbidites per 100,000 yr (Fig. 9) throughout the middle Miocene. Quartz-rich turbidites occur throughout this time, but at a rate of $<1 / 100,000 \mathrm{yr}$. Glauconite is the major dense mineral within the quartz-rich turbidites (Table 2; Sections 157-955A-50X-1 through $62 \mathrm{X}-4)$. Minor foraminifer-rich turbidites are present between 11.7 and 13.6 Ma. However, mixed and miscellaneous turbidites consisting of mixtures of volcanic lithic fragments and crystals, glauconite, foraminifers, and minor quartz are common.

Quartz-rich turbidites are not present at Site 956 during the midMiocene. Most of the nonvolcaniclastic turbidites are foraminiferrich (Fig. 4), with a few thin beds consisting of mixed foraminifers and volcanic lithics, and crystals.

Although Sites 955 and 956 do not provide evidence of the first occurrence of quartz-rich eolian-sand turbidite deposition, they are present in the middle Eocene to early Miocene at Deep Sea Drilling Project (DSDP) Sites 138, 139, and 140 (Fig. 1; Berger and von Rad, 1972). Turbidites deriving sediment from eolian sands thus occurred much earlier off northwestern Africa than indicated by the depths drilled at Sites 955 and 956.

At Site 955, between 15.8 and $14 \mathrm{Ma}$, there are 12 quartz-rich turbidites. Although no quartz-rich turbidites are present at Site 956 during the interval between 14.6 and $14 \mathrm{Ma}$, foraminifer-rich and mixed turbidites are present.

Between 14 and 13 Ma, Sarnthein et al. (1982) suggest that Africa was wetter, and although the sea level was relatively high compared to the late Miocene to Holocene (i.e., Haq et al., 1987), fluvial-mudderived turbidites were deposited at DSDP Site 397 (Fig. 2). At Site 955 , sediments within the approximate age range of 14 to 13 Ma contain only minor quartz-rich, foraminifer-rich, and mixed turbidites, indicating low turbidite depositional rates during this sea-level highstand.

Eolian-sand turbidites with ages between $\sim 12$ and $11 \mathrm{Ma}$ are noted at DSDP Sites 397 and 140 (Sarnthein, 1978; Sarnthein and Diester-Haass, 1977; Arthur et al., 1979; Sarnthein et al., 1982). At Sites 955 and 956, turbidite depositional rates are low approximately during this same time period, with most of the turbidites being mixtures of foraminifers, quartz, and volcanic lithic fragments.

Although extensive current erosion is responsible for a hiatus at Sites 366, 368, 369, and 397 in the upper part of the middle Miocene sediments (Arthur et al., 1979; Sarnthein et al., 1982), no apparent hiatus is present at Sites 955 and 956 during this time.

Thickly bedded and frequent volcaniclastic turbidites correlate to known phases of Miocene volcanic activity on Gran Canaria. The ba- 


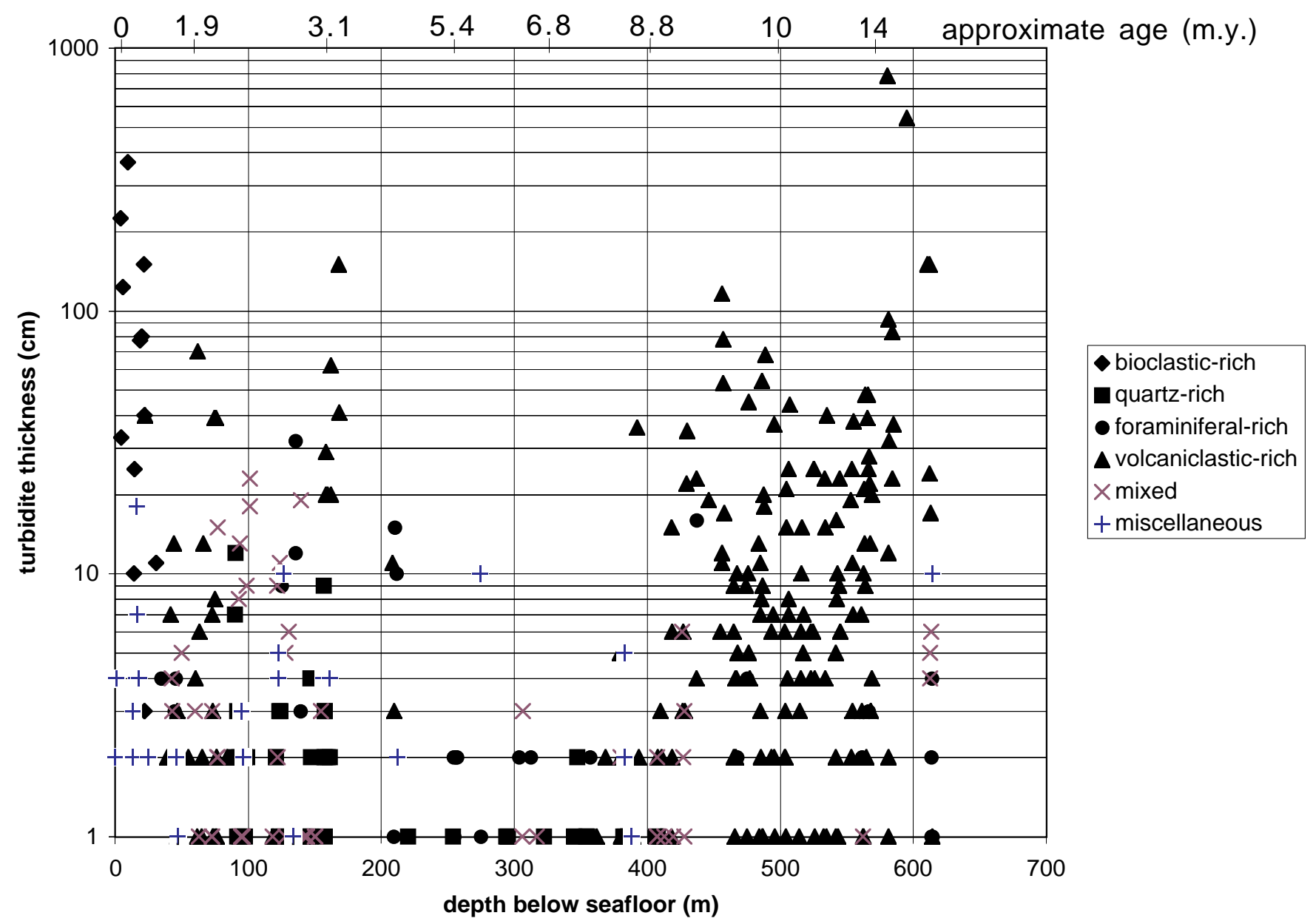

Figure 6. Plot of turbidite thickness (cm), depth below seafloor (m), and approximate age of sediment for the six major turbidite types at Site 956. Note that the $\mathrm{y}$-axis (turbidite thickness) is a log scale because of several very thickly bedded bioclastic-rich and volcaniclastic-rich turbidites.

saltic volcaniclastic deposits that occur at the base of both holes are related to the shield building phase of Gran Canaria (van den Bogaard and Schmincke, Chap. 11, this volume). At Site 955, between $\sim 15.1$ and $12.7 \mathrm{Ma}$, there is an abundance of felsic volcaniclastic material related to Mogán Group volcanism, which was active between 14 and 13.4 Ma on Gran Canaria (Schmincke, 1982). At Site 956, because of its close proximity to Gran Canaria, there is a large increase in the amount and thickness of felsic volcaniclastic turbidites between 14.6 and 13.67 Ma (Figs. 4, 6). Volcaniclastic detritus related to Fataga Group volcanism on Gran Canaria (13.4 to 9.5 Ma; Schmincke, 1982 ) is common in the core collected at both sites.

\section{Late Miocene (11.2 to 5.3 Ma)}

The late Miocene climate of northwestern Africa alternated between prolonged arid and shorter humid periods (Diester-Haass, 1977; 1979; Chamley and Diester-Haass, 1979). At $10 \mathrm{Ma}$, there was a dramatic sea-level fall related to the expansion of the Antarctic ice cap (Franks et al., 1992). At Site 955, between 9.99 and $9.4 \mathrm{Ma}$, there is a sharp increase in the number of quartz-rich turbidites (Fig. 3 ) with glauconite grains (Table 2). Mixed turbidites increase sharply between 10.8 and $9.99 \mathrm{Ma}$, and deposition remains high between 9.99 and 9.4 Ma. The mixed turbidites consist mostly of mixtures of quartz, foraminifers, and volcanic lithic fragments. There is also an increase in the number of foraminifer-rich turbidites and a minor increase in bioclastic turbidites deposited during this time range.

Nonvolcaniclastic turbidite depositional rates are nine turbidites/ 100 k.y. during the 9.99- and 9.4-Ma time range at Site 955 (Fig. 9), and coincide closely with the $10 \mathrm{Ma}$ drop in sea level. This large increase in continentally derived turbidites thus appears to be related to the fall in sea level at this time. Tectonic activity and associated erosion in the Atlas Mountains during the Miocene (Dillon and Sougy, 1974) may have increased sediment transport to the continental margin during this time. However, there is no apparent change in the provenance of the turbidite sands.

At Site 956, quartz-rich turbidites first appear during the 9.99 to 9.4-Ma time range. There is also an abundance of mixed and miscellaneous turbidites at this time (Fig. 4). The mixed turbidites fall into two types; quartz-volcanic lithic and foraminifer-volcanic lithic types. A hiatus in sedimentation is present at Site 956 between 10.8 and 9.9 Ma. As with Site 955, the increase in continentally derived turbidites between 9.99 and $9.4 \mathrm{Ma}$ at Site 956 corresponds to the sealevel fall at approximately this time.

Abundant turbidites associated with this sea-level fall were noted at DSDP Sites 397 and 140 (Arthur et al., 1979; Sarnthein et al., 1982). Excavation of canyons on the continental shelf, near Cape Bojador (Fig. 2), are believed to have developed during this lowstand (Arthur et al., 1979). 
Figure 7. Correlation diagram of number of slump deposits per calculated age ranges for Sites (A) 955 and (B) 956. Generalized lithostratigraphy is shown to the right of each column.
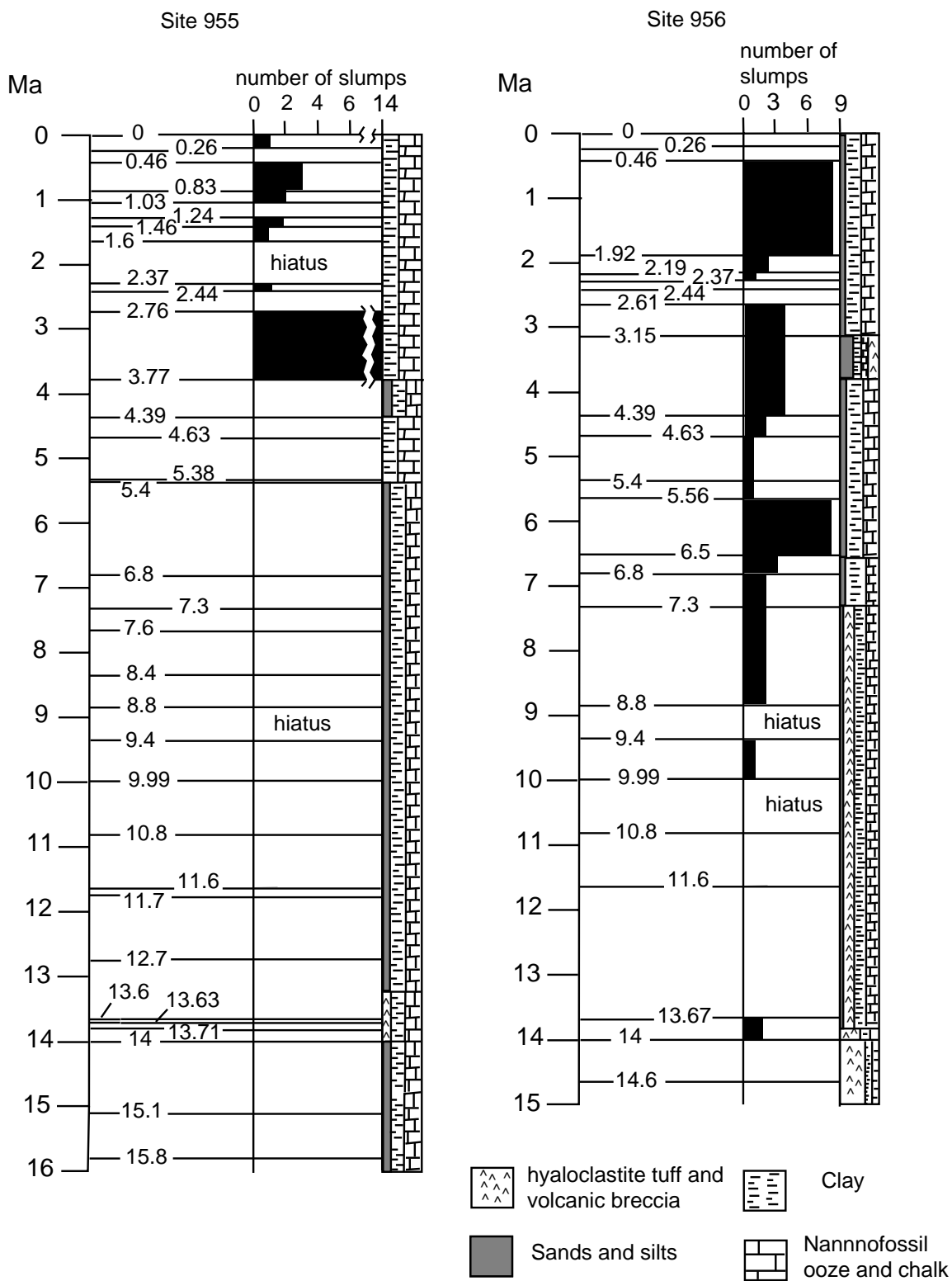

Ma

yaloclastite tuff and

Sands and silts
Another hiatus in sedimentation developed at both Sites 955 and 956 between 8.8 and 9.4 Ma. This hiatus also occurs at Site 954, north of Gran Canaria (Fig. 2). The cause of this hiatus is unclear but does affect deep marine sedimentation on both the north and south sides of the Canary Islands, suggesting bottom-current erosion around the Canary Islands. However, Sarnthein et al. (1982) suggest that bottom currents were weak and that there were no contourites at this time. Pronounced dissolution of calcium carbonate at depths $<3000 \mathrm{~m}$ (Sarnthein et al., 1982) may be responsible for the destruction of the biostratigraphic record at Site 955 , which is 2854 meters below sea level (mbsl), but would not account for the hiatuses at the deeper sites (Site 954 at 3485 mbsl and Site 956 at 3442 mbsl), suggesting currents may have been more important.

At Sites 955 and 956, deposition of quartz-rich turbidites with glauconite grains, mixed, and miscellaneous turbidites are abundant between 8.8 and $6.8 \mathrm{Ma}$ (Figs. 3, 4). Minor bioclastic- and foraminifer-rich turbidites occur at Site 955.

Nonvolcaniclastic turbidite depositional rates are much higher at Site 955, as much as eight turbidites/100 k.y., than at Site 956, which are only as high as 2.5 turbidites/100 k.y. (Fig. 9). However, for the remainder of the late Miocene and into the early Pliocene, there is a cessation of turbidite activity at Site 955. At Site 956, quartz-rich turbidite deposition continues to the end of the Miocene, and submarine slumping increases (Figs. 4, 7). At DSDP Site 397, <50 km south of Site 955 (Fig. 2), quartz-rich turbiditic sands containing glauconite grains continued to be deposited during the late Miocene and early Pliocene (Diester-Haass, 1979; Chamley and Diester-Haass, 1979). During this time ( $\sim 6.8$ to $5.3 \mathrm{Ma}$ ), continentally derived turbidites therefore may have bypassed Site 955 with minor deposition at Site 956, but with no significant change in turbidite deposition to the south of these sites off Cape Bojador.

There was a hiatus in volcanism and a major erosional phase on Gran Canaria from 9.5 to 4.5 Ma (Schmincke, 1982). At Site 955, the predominance of hemipelagic sedimentation indicates that this area was cutoff from terrigenous sedimentation from both the Canary Islands and the continent during the latter part of the erosional phase. Minor turbidite beds are present at Site 956, consisting of mixtures of quartz, foraminifers, and volcaniclastic components. The volcanic 
Table 3. Summary of depths and probable ages of slump and slide deposits at Sites 955 and 956.

\begin{tabular}{|c|c|c|c|c|}
\hline $\begin{array}{c}\text { Folded/slumped interval } \\
\begin{array}{c}\text { Core, section, } \\
\text { interval }(\mathrm{cm})\end{array} \\
\end{array}$ & $\begin{array}{l}\text { Data } \\
\text { type }\end{array}$ & $\begin{array}{c}\text { Depth } \\
\text { (m) }\end{array}$ & $\begin{array}{l}\text { Approximate } \\
\text { age range } \\
(\mathrm{Ma})\end{array}$ & $\begin{array}{c}\text { Age of } \\
\text { slump blocks } \\
\text { (Ma) }\end{array}$ \\
\hline $\begin{array}{l}157-955 \mathrm{~A}- \\
3 \mathrm{H}-1 \\
5 \mathrm{H}-1 \\
6 \mathrm{H}-2 \text { to } 6 \mathrm{H}-4 \\
6 \mathrm{H}-6 \text { to } 6 \mathrm{H}-7 \\
7 \mathrm{H}-7 \text { to } 7 \mathrm{H}-\mathrm{CC} \\
8 \mathrm{H}-2 \text { to } 8 \mathrm{H}-3 \\
9 \mathrm{H}-5 \\
10 \mathrm{H}-1 \text { to } 10 \mathrm{H}-3 \\
11 \mathrm{H}-1 \text { to } 11 \mathrm{H}-\mathrm{CC} \\
12 \mathrm{H}-\mathrm{CC} \\
13 \mathrm{H}-\mathrm{CC} \\
14 \mathrm{H}-6 \\
14 \mathrm{H}-\mathrm{CC} \\
14 \mathrm{H}-\mathrm{CC} \\
15 \mathrm{H}-\mathrm{CC} \\
16 \mathrm{H}-1 \\
17 \mathrm{H}-2 \text { to } 17 \mathrm{H}-4 \\
17 \mathrm{H}-6 \text { to } 17 \mathrm{H}-\mathrm{CC} \\
18 \mathrm{H}-1 \text { to } 18 \mathrm{H}-\mathrm{CC} \\
19 \mathrm{X}-1 \\
19 \mathrm{X}-1 \text { to } 19 \mathrm{X}-2 \\
19 \mathrm{X}-2 \\
19 \mathrm{X}-4 \\
20 \mathrm{X}-1\end{array}$ & $\begin{array}{l}\text { Lithostrat. } \\
\text { Lithostrat. } \\
\text { Lithostrat. } \\
\text { Lithostrat. } \\
\text { Lithostrat. } \\
\text { Lithostrat. } \\
\text { Lithostrat. } \\
\text { Lithostrat. } \\
\text { Lithostrat. } \\
\text { Biostrat. } \\
\text { Biostrat. } \\
\text { Biostrat. } \\
\text { Biostrat. } \\
\text { Biostrat. } \\
\text { Biostrat. } \\
\text { Biostrat. } \\
\text { Lithostrat. } \\
\text { Lithostrat. } \\
\text { Lithostrat. } \\
\text { Lithostrat. } \\
\text { Lithostrat. } \\
\text { Lithostrat. } \\
\text { Lithostrat. } \\
\text { Lithostrat. }\end{array}$ & $\begin{array}{c}17.6-19.0 \\
37.0-38.0 \\
47.6-52.0 \\
53.6-55.8 \\
64.6-65.8 \\
66.6-69.6 \\
80.6-82.0 \\
84.0-88.6 \\
93.6-103.4 \\
112.7-112.9 \\
122.3-122.5 \\
130.2 \\
131.8 \\
131.8-132.0 \\
141.2-141.4 \\
141.9 \\
153.2-156.2 \\
158.0-160.6 \\
160.8-168.4 \\
169.2-169.6 \\
170.0-171.0 \\
171.5-171.9 \\
173.7-174.8 \\
176.4-176.7\end{array}$ & $\begin{array}{l}0.0-0.26 \\
0.46-0.83 \\
0.46-0.83 \\
0.46-0.83 \\
0.83-1.03 \\
0.83-1.03 \\
1.03-1.24 \\
1.24-1.46 \\
1.46-1.60 \\
2.37-2.44 \\
2.76-3.77 \\
2.76-3.77 \\
2.76-3.77 \\
2.76-3.77 \\
2.76-3.77 \\
2.76-3.77 \\
2.76-3.77 \\
2.76-3.77 \\
2.76-3.77 \\
2.76-3.77 \\
2.76-3.77 \\
2.76-3.77 \\
2.76-3.77 \\
2.76-3.77\end{array}$ & $\begin{array}{c} \\
\\
\\
\\
\\
\\
\\
1.92 \\
3 \\
3.0-3.15 \\
4 \\
4.39 \\
4.53-5.4 \\
3.15 \\
5.56\end{array}$ \\
\hline $\begin{array}{l}157-956 \mathrm{~A}- \\
3 \mathrm{H}-6 \\
4 \mathrm{H}-1 \text { to } 4 \mathrm{H}-4 \\
4 \mathrm{H}-5 \\
6 \mathrm{H}-2 \\
6 \mathrm{H}-\mathrm{CC} \\
7 \mathrm{H}-1 \text { to } 7 \mathrm{H}-2 \\
7 \mathrm{H}-4 \\
7 \mathrm{H}-5 \\
8 \mathrm{H}-4 \text { to } 8 \mathrm{H}-5 \\
9 \mathrm{H}-5 \text { to } 9 \mathrm{H}-6 \\
9 \mathrm{H}-7 \\
10 \mathrm{H}-5 \\
12 \mathrm{H}-1 \text { to } 13 \mathrm{H}-5 \\
14 \mathrm{H}-6 \text { to } 14 \mathrm{H}-\mathrm{CC} \\
15 \mathrm{H}-1 \text { to } 15 \mathrm{H}-2 \\
16 \mathrm{H}-1 \text { to } 16 \mathrm{H}-2\end{array}$ & $\begin{array}{l}\text { Lithostrat. } \\
\text { Lithostrat. } \\
\text { Lithostrat. } \\
\text { Lithostrat. } \\
\text { Biostrat. } \\
\text { Lithostrat. } \\
\text { Lithostrat. } \\
\text { Biostrat. } \\
\text { Lithostrat. } \\
\text { Lithostrat. } \\
\text { Lithostrat. } \\
\text { Lithostrat. } \\
\text { Lithostrat. } \\
\text { Lithostrat. } \\
\text { Lithostrat. } \\
\text { Lithostrat. }\end{array}$ & $\begin{array}{c}23.0-24.6 \\
25.0-31.0 \\
32.0-32.3 \\
46.0-46.5 \\
50.43 \\
53.6-56.6 \\
59.0-59.2 \\
60.1 \\
67.6-70.6 \\
78.6-80.5 \\
81.6-82.2 \\
88.0-89.5 \\
101.0-118.0 \\
127.6-130.0 \\
130.8-131.3 \\
139.0-140.9\end{array}$ & $\begin{array}{l}0.46-1.92 \\
0.46-1.92 \\
0.46-1.92 \\
0.46-1.92 \\
0.46-1.92 \\
0.46-1.92 \\
0.46-1.92 \\
0.46-1.92 \\
2.19-2.37 \\
2.19-2.37 \\
2.19-2.37 \\
2.61-3.15 \\
2.61-3.15 \\
2.61-3.15 \\
2.61-3.15 \\
2.61-3.15\end{array}$ & 1.95 \\
\hline $\begin{array}{l}\text { 157-956B- } \\
\text { 1R-1 } \\
\text { 5R-2 } \\
\text { 5R-4 } \\
\text { 5R-CC } \\
\text { 6R-1 to 6R--2 } \\
\text { 6R-CC } \\
\text { 7R-1 to } 7 R-3 \\
\text { 10R-2 to } 10 \mathrm{R}-4 \\
\text { 11R-3 to } 11 \mathrm{R}-4 \\
\text { 12R-1 to } 12 \mathrm{R}-2 \\
\text { 14R-1 to } 15 \mathrm{R}-1 \\
\text { 15R-5 } \\
\text { 15R-6 } \\
\text { 16R-1 } \\
\text { 16R-4 } \\
\text { 17R-1 } \\
\text { 17R-2 } \\
17 \mathrm{R}-4\end{array}$ & $\begin{array}{l}\text { Lithostrat. } \\
\text { Lithostrat. } \\
\text { Lithostrat. } \\
\text { Biostrat. } \\
\text { Lithostrat. } \\
\text { Biostrat. } \\
\text { Lithostrat. } \\
\text { Lithostrat. } \\
\text { Lithostrat. } \\
\text { Lithostrat. } \\
\text { Lithostrat. } \\
\text { Lithostrat. } \\
\text { Lithostrat. } \\
\text { Lithostrat. } \\
\text { Lithostrat. } \\
\text { Lithostrat. } \\
\text { Lithostrat. } \\
\text { Lithostrat. }\end{array}$ & $\begin{array}{c}157.0-157.7 \\
195.4-198.4 \\
200.0-200.6 \\
203.7 \\
205.0-208.0 \\
212.2 \\
214.7-218.0 \\
245.0-249.6 \\
257.0-258.4 \\
262.8-265.8 \\
282.0-291.7 \\
298 \\
299.5 \\
301.3-302.8 \\
307 \\
311.1-311.4 \\
313.6-313.7 \\
316.2-316.4\end{array}$ & $\begin{array}{l}2.61-3.15 \\
3.15-4.39 \\
3.15-4.39 \\
3.15-4.39 \\
3.15-4.39 \\
4.39-4.63 \\
4.39-4.63 \\
4.63-5.40 \\
5.40-5.56 \\
5.56-6.50 \\
5.56-6.50 \\
5.56-6.50 \\
5.56-6.50 \\
5.56-6.50 \\
5.56-6.50 \\
5.56-6.50 \\
5.56-6.50 \\
6.50-6.80\end{array}$ & $\begin{array}{l}4.63 \\
4.63\end{array}$ \\
\hline $\begin{array}{l}157-956 \mathrm{R}- \\
18 \mathrm{R}-2 \text { to } 19 \mathrm{R}-1 \\
19 \mathrm{R}-3 \text { to } 19 \mathrm{R}-4 \\
21 \mathrm{R}-6 \text { to } 22 \mathrm{R}-1 \\
22 \mathrm{R}-3 \text { to } 22 \mathrm{R}-6 \\
23 \mathrm{R}-1 \text { to } 23 \mathrm{R}-2 \\
24 \mathrm{R}-5 \text { to } 24 \mathrm{R}-6 \\
30 \mathrm{R}-1 \\
37 \mathrm{R}-1 \text { to } 37 \mathrm{R}-3 \\
38 \mathrm{R}-2 \text { to } 39 \mathrm{R}-1\end{array}$ & $\begin{array}{l}\text { Lithostrat. } \\
\text { Biostrat. } \\
\text { Lithostrat. } \\
\text { Lithostrat. } \\
\text { Lithostrat. } \\
\text { Lithostrat. } \\
\text { Biostrat. } \\
\text { Biostrat. } \\
\text { Biostrat. }\end{array}$ & $\begin{array}{c}323.0-330.5 \\
333.2-344.7 \\
356.7-360.4 \\
361.9-367.4 \\
369.0-370.0 \\
383.9-386.2 \\
436.5 \\
504.3-506.6 \\
515.1-522.7\end{array}$ & $\begin{array}{c}6.50-6.80 \\
6.50-6.80 \\
6.80-7.30 \\
6.80-8.80 \\
7.30-8.80 \\
7.30-8.80 \\
9.40-9.99 \\
13.67-14.00 \\
13.67-14.00\end{array}$ & $\begin{array}{l}10.4 \\
14.05 \\
14.16\end{array}$ \\
\hline
\end{tabular}

Notes: Lithostratigraphic data from slump locations were determined from core analysis of folded or disrupted sediment. Biostratigraphic data for slumped intervals were determined by the presence of older microfossils within sediment that was overlain and underlain by sequences of undisturbed sediment containing younger microfossils (biostratigraphic data from Shipboard Scientific Party, 1995c, 1995d). lithics are mostly vitric and lathwork (mafic) fragments, suggesting that they were derived from Tenerife shield volcanism active at this time (Schmincke, 1982) rather than erosion of felsic material from Gran Canaria. During the major erosional phase on Gran Canaria, the bulk of the sediment appears to have been shed to the northeast (H.U. Schmincke, pers. comm., 1995; Schneider et. al., Chap. 17, this volume) and accounts for the lack of volcanic material from Gran Canaria at these southern sites.

\section{Pliocene (5.3 to 1.6 Ma)}

Hemipelagic sedimentation dominated during the early part of the Pliocene ( $\sim 5.3$ to $4.39 \mathrm{Ma})$ at Sites 955 and 956 . Only minor continentally derived turbidites were deposited at Site 956 during this time (Fig. 4). Continentally derived turbidites continue to be deposited at DSDP Site 397 (Diester-Haass, 1979; Chamley and Diester-Haass, 1979).

The Roque Nublo phase of volcanism was active during 4.3-3.5 Ma on Gran Canaria (Schmincke, 1982), but did not contribute detritus to these sites. Because prior erosion had deeply dissected the northern part of Gran Canaria, the bulk of the Roque Nublo volcanics were deposited on the northern half of the island (H.-U. Schmincke, pers. comm., 1995).

Three large magnitude sea-level falls occurred at $\sim 3.8,2.4$, and 1.6 Ma, related to the onset of glaciation in the Northern Hemisphere and an increase in Southern Hemisphere glaciation (Ciesielski et al., 1982; Shackleton et al., 1984; Franks et al., 1992; Tiedemann et al., 1994). At Site 955 , between 3.77 and $2.76 \mathrm{Ma}$, there was a sharp increase in quartz-rich turbidite deposition (Fig. 3). Although not conclusive, because of the large calculated age range during this increase in continentally derived turbidite deposition, it is likely that this increase occurred during the first of the large magnitude sea-level falls. A large number of slump deposits (14 slumps) also occur at Site 955 during this time.

At Site 956, deposition of quartz-rich turbidites sharply increases between 4.39 and 3.15 Ma and again between 3.15 and 2.61 Ma. Foraminifer-rich turbidites and mixed turbidites (consisting mostly of either mixtures of quartz and foraminifers or quartz, volcanic lithics, and crystals) also increase in abundance at this time. Nonvolcaniclastic turbidite depositional rates are the highest between 3.15 and 2.61 Ma; 20 turbidites/100 k.y. (Fig. 9). Between 4.39 and 2.61 Ma, slump activity also increased.

An increase in turbidite deposition is also noted at DSDP Sites 367 and 397 (Diester-Haass, 1979; Sarnthein et al., 1982) during the late Pliocene. An abrupt increase in eolian sand turbidites is attributed to large magnitude sea-level falls at these sites (Sarnthein et al., 1982).

Slump blocks, at Site 955, between 2.4 and 2.7 Ma, were derived from sediments ranging in age from 3 to $5.56 \mathrm{Ma}$. Slumped intervals have slightly different interbedded lithologies than the coherent strata above and below the disrupted sequences, suggesting that the slumped sediment may have moved considerable distances. Intensified North Atlantic Deep Water causing seafloor erosion (Franks et al., 1982), coastal upwelling noted at Site 397 (Sarnthein et al., 1982; Tiedemann et al., 1989; Jacobi and Hayes, 1992), and a Pliocene angular unconformity present on the shelf and upper slope off northwestern African (Von Rad and Wissmann, 1982) may be evidence that current erosion and high biogenic gas concentrations along the continental slope are the cause of these slope failures. Additionally, the hiatus at Site 955 (1.6 to $2.37 \mathrm{Ma}$ ) may be related to current erosion.

\section{Quaternary (1.6 to 0 Ma)}

The Pleistocene is characterized by numerous periods of humid and arid climatic changes and corresponding sea-level fluctuations 
a)

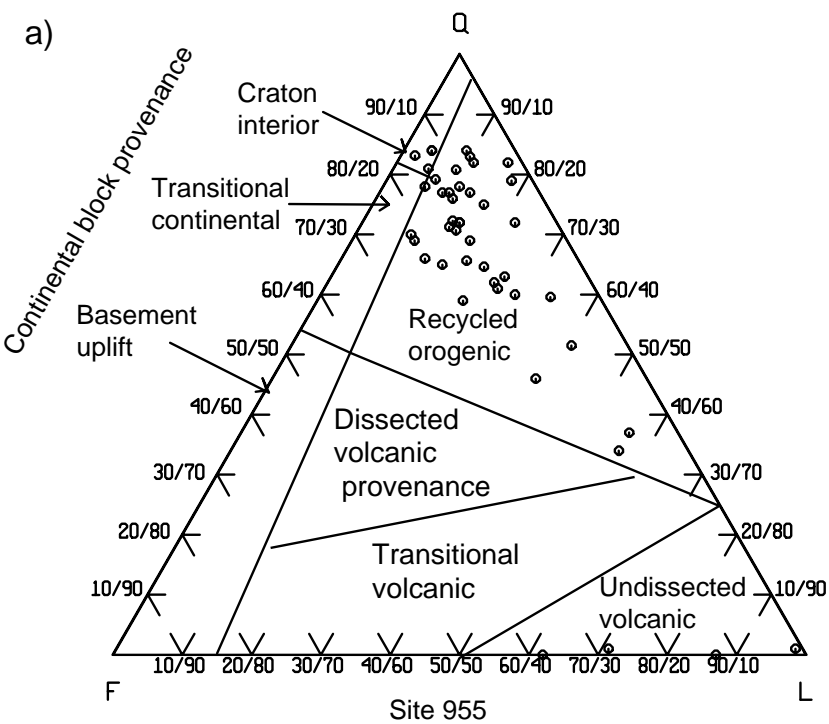

b)

Figure 8. Ternary quartz (Q), feldspar (F), and lithic (L) plots for petrographic samples from Sites (A) 955 and (B) 956. Provenance fields modified from Dickinson et al. (1983).

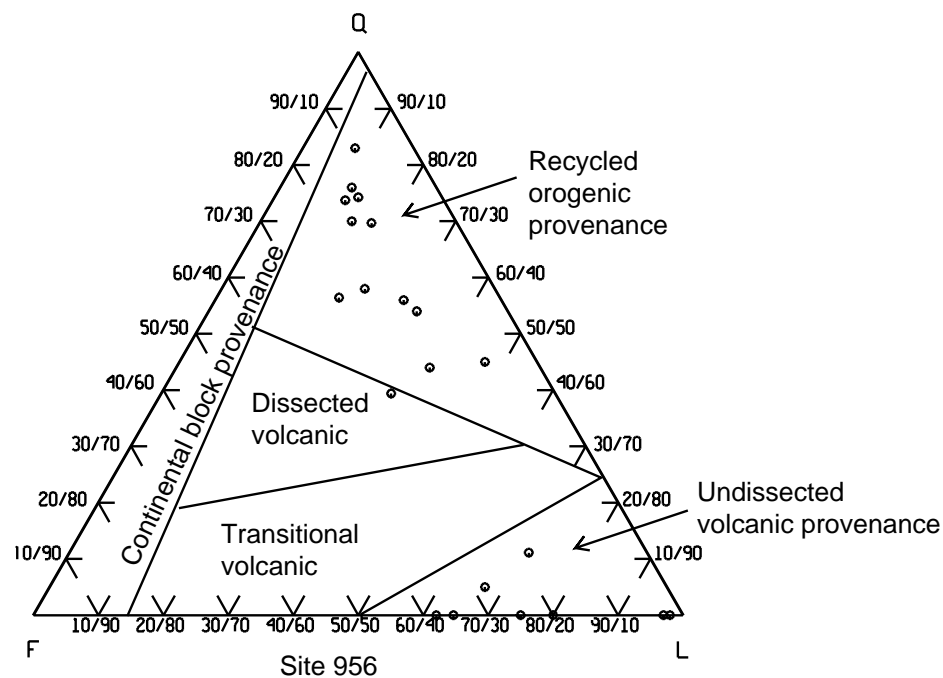

(Diester-Haass, 1977, 1979; Chamley and Diester-Haass, 1979; Sarnthein et al., 1982; Sarnthein and Tiedemann, 1989). Many areas of the northwestern African shelf developed erosional surfaces and relict deposits during Pleistocene regressions (Dillon and Sougy, 1974). Eolian sands eroded during these regressions were redeposited seaward. The quartz-rich turbidites at Site 955 therefore may have been derived from shelf erosion during early Pleistocene sea-level falls.

Both sites also have an increase in the number of foraminifer-rich turbidites as well as thick bioclastic deposits consisting of shallow marine organisms throughout the Quaternary. As noted previously, the most likely source of the shallow marine bioclastic material is from the southern Canary Islands rather than the African shelf. These thick bioclastic units may represent slides of shallow marine sediment flanking the Canary Islands as sea levels changed. However, several bioclastic beds at Site 956 contain 5\%-20\% volcaniclastic material (i.e., Cores 157-956A-1H, $2 \mathrm{H}$, and $3 \mathrm{H}$ ). Volcanic flows into the shallow marine environment of Gran Canaria is a likely cause of these turbidite deposits.

Slump and slide deposits are abundant throughout the Quaternary at Site 955 and are more frequent on the lower flank of Gran Canaria at Site 956. Upwelling and bottom-water erosion (Arthur et al., 1979;
Sarnthein et al., 1982; Tiedemann et al., 1989; Jacobi and Hayes, 1992) and an increase in turbidites, slides, slumps, and submarine canyon erosion (von Rad and Wissmann, 1982; Masson et al., 1992) have also been noted along the continental margin of northwestern Africa. Current erosion may be responsible for some of these masswasting events at Sites 955 and 956. Also, because Site 956 is located on the flank of Gran Canaria, increased sedimentation and/or earthquakes associated with volcanism on the island most likely contributed to some of these mass-wasting events.

\section{SUMMARY}

Turbidite and slump deposits recovered south of the Canary Islands at Sites 955 and 956 provide a record of both continental sedimentation from northwestern Africa and volcaniclastic sedimentation from the Canary Islands. Although age constraints are not precisely defined in these cores, the general trend of sedimentation is consistent with sea-level variations being responsible for transport of the continentally derived turbidites. An increase in the number of volcaniclastic turbidites closely corresponds to known periods of volcanism on the Canary Islands. 


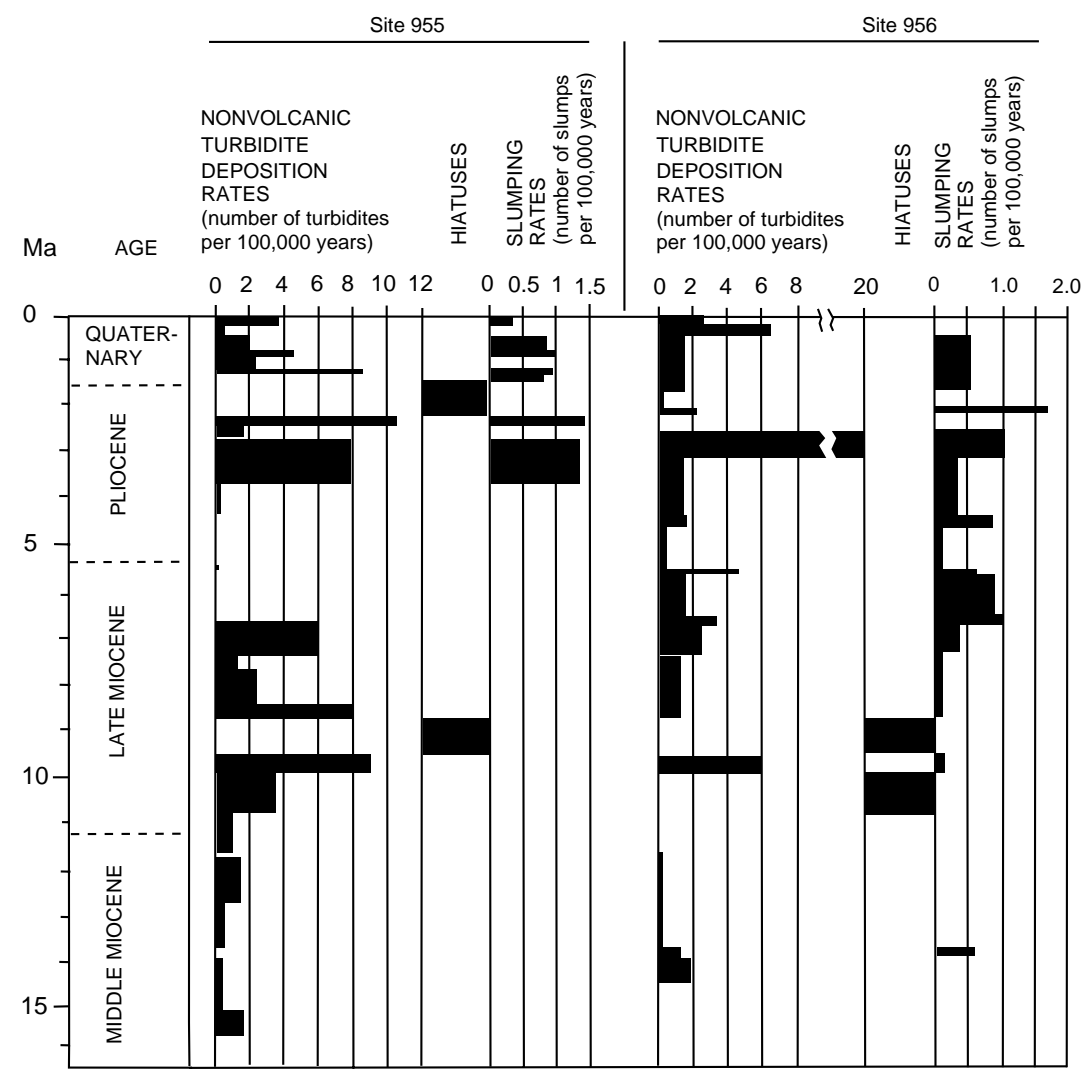

Figure 9. Correlation diagram for nonvolcaniclastic turbidite depositional rates and slumping rates (calculated for number of events per $100 \mathrm{k} . \mathrm{y}$., using age ranges shown in Table 1) for Sites 955 and 956. Time ranges for hiatuses are also shown for each site. Time scale from Palmer (1983).
Quartz-rich turbidites composed of well-rounded, very finegrained sand are present throughout the middle Miocene to Quaternary sediments at Site 955 . Abundant quartz-rich turbidites occur between 2.76 and 3.77, 8.4 and 8.8 , and 9.4 and $9.99 \mathrm{Ma}$. The increase of these turbidites generally corresponds to changes in sea level with sediment derived from Saharan sands that had migrated onto the subaerially exposed continental shelf and were shed into the deep marine environment.

An increase in other detritus, such as shallow marine bioclastic material and foraminifer-rich turbidites, also corresponds to periods of sea-level fluctuation. Very thickly bedded turbidites composed of shallow marine bioclastic material (derived from the Canary Islands) were mostly deposited during the Pleistocene at Site 956. Thinner bioclastic deposits occur at Site 955 during the Pleistocene, late Pliocene, and late Miocene.

Large-scale submarine slumping appears to be, in part, related to periods of increased bottom current erosion and upwelling. The frequent slumping events at Site 956, on the lower flank of Gran Canaria, may have also resulted from increased sedimentation and/or earthquakes associated with Canary volcanism.

\section{ACKNOWLEDGMENTS}

Support for this research was provided by the JOI/U.S. Science Support Program. I wish to thank U. von Rad and an anonymous reviewer for their helpful comments and suggestions.

\section{REFERENCES}

Arthur, M.A., von Rad, U., Cornford, C., McCoy, F.W., and Sarnthein, M., 1979. Evolution and sedimentary history of the Cape Bojador continental margin, northwestern Africa. In von Rad, U., Ryan W.B.F., et al., Init. Repts. DSDP, 47 (Pt. 1): Washington (U.S. Govt. Printing Office), 773816.
Auffret, G.A., Le Suave, R., Kerbrat, R., Sichler, B., Roy, S.L., and Muller, C., 1984. Sedimentation in the southern Cape Verde Basin: seismic and sediment facies. In Stow, D.A.V., and Piper, D.J.W. (Eds.), Fine-grained Sediments: Deep-water Processes and Facies. Geol. Soc. Spec. Publ. London, 15:153-167.

Berger, W.H., and von Rad, U., 1972. Cretaceous and Cenozoic sediments from the Atlantic Ocean. In Hayes, D.E., Pimm, A.C., et al., Init. Repts. DSDP, 14: Washington (U.S. Govt. Printing Office), 787-954.

Chamley, H., and Diester-Haass, L., 1979. Upper Miocene to Pleistocene climates in northwest Africa deduced from terrigenous components of Site 397 sediments (DSDP Leg 47A). In von Rad, U., Ryan, W.B.F., et al., Init. Repts. DSDP, 47: Washington (U.S. Govt. Printing Office), 641646.

Ciesielski, P.F., Ledbetter, M.T., and Ellwood, B.B., 1982. The development of Antarctic glaciation and the Neogene paleoenvironment of the Maurice Ewing Bank. Mar. Geol., 46:1-51.

Dickinson, W.R., 1970. Interpreting detrital modes of graywacke and arkose. J. Sediment. Petrol., 40:695-707.

Dickinson, W.R., Beard, L.S., Brakenridge, G.R., Erjavec, J.L., Ferguson, R.C., Inman, K.F., Knepp, R.A., Lindberg, F.A., and Ryberg, P.T., 1983. Provenance of North American Phanerozoic sandstones in relation to tectonic setting. Geol. Soc. Am. Bull., 94:222-235.

Diester-Haass, L., 1977. Influence of carbonate dissolution, climate, sealevel changes and volcanism on Neogene sediments off northwest Africa (Leg 41). In Lancelot, Y., Seibold, E., et al., Init. Repts. DSDP, 41: Washington (U.S. Govt. Printing Office), 1033-1047.

, 1979. DSDP Site 397: climatological, sedimentological, and oceanographic changes in the Neogene autochthonous sequence. In von Rad, U., Ryan, W.B.F., et al., Init. Repts. DSDP, 47: Washington (U.S. Govt. Printing Office) 647-670.

Dillon, W.P., and Sougy, J.M.A., 1974. Geology of West Africa and Canary and Cape Verde islands. In Nairn, A.E.M., and Stehli, F.G. (Eds.), The Ocean Basins and Margins (Vol. 2): The North Atlantic: New York (Plenum), 315-390.

Faugères, J.C., Legigan, P., Maillet, N., Sarnthein, M., and Stein, R., 1989. Characteristics and distribution of Neogene turbidites at Site 657 (Leg 108, Cap Blanc continental rise, Northwest Africa): variations in turbidite source and continental climate. In Ruddiman, W., Sarnthein, M., et al., 
Proc. ODP, Sci. Results, 108: College Station, TX (Ocean Drilling Program), 329-348.

Franks, L.A., Francis, J.E., and Syktus, J.I., 1992. Climatic Modes of the Phanerozoic: the History of the Earth's Climate Over the Past 600 Million Years: New York (Cambridge Univ. Press).

Haq, B.U., Hardenbol, J., and Vail, P.R., 1987. Chronology of fluctuating sea levels since the Triassic. Science, 235:1156-1167.

Ingersoll, R.V., Bullard, T.F., Ford, R.L., Grimm, J.P., Pickle, J.D., and Sares, S.W., 1984. The effect of grain size on detrital modes: a test of the GazziDickinson point-counting method. J. Sediment. Petrol., 54:103-116.

Jacobi, R.J., and Hayes, D.E., 1992. Northwest African continental rise: effects of near-bottom processes interred from high-resolution seismic data. In Poag, C.W., and de Graciansky, P.C. (Eds.), Geological Evolution of Atlantic Continental Rises: New York (van Nostrand Reinhold), 293326.

Masson, D.G., Kidd, R.B., Gardner, J.V., Huggett, Q.J., and Weaver, P.P.E., 1992. Saharan Continental Rise: sediment facies distribution and sediment slides. In Poag, C.W., and de Graciansky, P.C. (Eds.), Geologic Evolution of Atlantic Continental Rises: New York (van Nostrand Reinhold), 327-343.

McDougall, I., and Schmincke, H.-U., 1977. Geochronology of Gran Canaria, Canary Islands: age of shield-building volcanism and other magmatic phases. Bull. Volcanol., 40:1-21.

Palmer, A.R., 1983. The Decade of North American Geology 1983 geologic time scale. Geology, 11:504.

Porrenga, D.H., 1967. Glauconite and chamosite as depth indicators in the marine environment. In Hallam, A. (Ed.), Depth Indicators in Marine Sedimentary Rocks. Mar. Geol., Spec. Iss., 5:495-502.

Ranke, U., Von Rad, U., and Wissmann G., 1982. Stratigraphy, facies and tectonic development of the on- and offshore Aaiun-Tarfaya Basin: a review. In von Rad, U., et al. (Eds.), Geology of the Northwest African Continental Margin: New York (Springer-Verlag), 273-299.

Sarnthein, M., 1978. Neogene sand layers off northwest Africa: composition and source environment. In Lancelot, Y., Seibold, E., et al., Init. Repts. DSDP, Suppl. to vols. 38, 39, 40, and 41: Washington (U.S. Govt. Printing Office), 939-959.

Sarnthein, M., and Diester-Haass, L., 1977. Eolian-sand turbidites. J. Sediment. Petrol., 47:868-890.

Sarnthein, M., Thiede, J., Pflaumann, U., Erlenkeuser, H., Fütterer, D., Koopmann, B., Lange, H., and Seibold, E., 1982. Atmospheric and oceanic circulation patterns off Northwest Africa during the past 25 million years. In von Rad, U., Hinz, K., Sarnthein, M., Seibold, E. (Eds.), Geology of the Northwest African Continental Margin: Berlin (Springer Verlag), 545604.

Sarnthein, M., and Tiedemann, R., 1989. Toward a high-resolution stable isotope stratigraphy of the last 3.4 million years: Sites 658 and 659 off northwest Africa. In Ruddiman, W., Sarnthein, M., et al., Proc. ODP, Sci. Results, 108: College Station, TX (Ocean Drilling Program), 167-185.

Schmincke, H.-U., 1982. Volcanic and chemical evolution of the Canary Islands. In von Rad, U., Hinz, K., Sarnthein, M., and Seibold, E. (Eds.), Geology of the Northwest African Continental Margin: Berlin (Springer), 273-306.

Schmincke, H.-U., and von Rad, U., 1979. Neogene evolution of Canary Island volcanism inferred from ash layers and volcaniclastic sandstones of DSDP Site 397 (Leg 47A). In von Rad, U., Ryan, W.B.F., et al., Init. Repts. DSDP, 47 (Pt. 1): Washington (U.S. Govt. Printing Office), 703725.

Schmincke, H.-U., Weaver, P.P.E., Firth, J.V., et al., 1995. Proc. ODP, Init. Repts., 157: College Station, TX (Ocean Drilling Program).

Shackleton, N.J., Backman, J., Zimmerman, H., Kent, D.V., Hall, M.A., Roberts, D.G., Schnitker, D., Baldauf, J.G., Desprairies, A., Homrighausen, R., Huddlestun, P., Keene, J.B., Kaltenback, A.J., Krumsiek, K.A.O., Morton, A.C., Murray, J.W., and Westberg-Smith, J., 1984. Oxygen isotope calibration of the onset of ice-rafting and history of glaciation in the North Atlantic region. Nature, 307:620-623.

Shipboard Scientific Party, 1995a. Explanatory notes. In Schmincke, H.-U., Weaver, P.P.E., Firth, J.V., et al., Proc. ODP, Init. Repts., 157: College Station, TX (Ocean Drilling Program), 27-48.

1995b. Site 954. In Schmincke, H.-U., Weaver, P.P.E., Firth, J.V., et al., Proc. ODP, Init. Repts., 157: College Station, TX (Ocean Drilling Program), 395-431.

, 1995c. Site 955. In Schmincke, H.-U., Weaver, P.P.E., Firth, J.V., et al., Proc. ODP, Init. Repts., 157: College Station, TX (Ocean Drilling Program), 433-496.

, 1995d. Site 956. In Schmincke, H.-U., Weaver, P.P.E., Firth, J.V., et al., Proc. ODP, Init. Repts., 157: College Station, TX (Ocean Drilling Program), 497-557.

Staudigel, H., and Schmincke, H.-U., 1984. The Pliocene seamount series of La Palma/Canary Islands. J. Geophys. Res., 89:11195-11215.

Stets, J., and Wurster, P., 1982. Atlas and Atlantic: structural relations. In von Rad, U., et al. (Eds.), Geology of the Northwest African Continental Margin: New York (Springer-Verlag), 69-85.

Tiedemann, R., Sarnthein, M., and Shackleton, N.J., 1994. Astronomic timescale for the Pliocene Atlantic $\delta^{18} \mathrm{O}$ and dust flux records of Ocean Drilling Program Site 659. Paleoceanography, 9:619-638.

Tiedemann, R., Sarnthein, M., and Stein, R., 1989. Climatic changes in the western Sahara: aeolo-marine sediment record of the last 8 million years (Sites 657-661). In Ruddiman, W., Sarnthein, M., et al., Proc. ODP, Sci. Results, 108: College Station, TX (Ocean Drilling Program), 241-277.

von Rad, U., and Wissmann, G., 1982. Cretaceous-Cenozoic history of the West Saharan continental margin (NW Africa): development, destruction and gravitational sedimentation. In von Rad, U., et al. (Eds.), Geology of the Northwest African Continental Margin: New York (Springer-Verlag), 106-131.

Weaver, P.P.E., and Kuijpers, A., 1983. Climatic control of turbidite deposition on the Madeira Abyssal Plain. Nature, 306:360-363.

Weaver, P.P.E., Searle, R.C., and Kuijpers, A., 1986. Turbidite deposition and the origin of the Madeira Abyssal Plain. In Summerhayes, C.P., and Shackleton, N.J. (Eds.), North Atlantic Palaeoceanography. Spec. Publ. Geol. Soc. London, 21:131-143.

Date of initial receipt: 16 January 1996

Date of acceptance: 28 April 1997

Ms 157SR-122 
Appendix A. Grain-size distributions for selected samples from Sites 955 and 956.

\begin{tabular}{|c|c|c|c|c|c|c|c|}
\hline $\begin{array}{l}\text { Core, section, } \\
\text { interval }(\mathrm{cm})\end{array}$ & $\begin{array}{l}<0.063 \\
(\mathrm{~mm})\end{array}$ & $\begin{array}{l}0.063 \\
(\mathrm{~mm})\end{array}$ & $\begin{array}{l}0.125 \\
(\mathrm{~mm})\end{array}$ & $\begin{array}{l}0.18 \\
(\mathrm{~mm})\end{array}$ & $\begin{array}{l}0.25 \\
(\mathrm{~mm})\end{array}$ & $\begin{array}{l}0.354 \\
(\mathrm{~mm})\end{array}$ & $\begin{array}{c}0.5 \\
(\mathrm{~mm})\end{array}$ \\
\hline \multicolumn{8}{|l|}{$157-955 \mathrm{~A}-$} \\
\hline $8 \mathrm{H}-4,60-62$ & 0.19 & 0.61 & 0.08 & 0.05 & 0.04 & 0.04 & 0.00 \\
\hline $8 \mathrm{H}-6,47-49$ & 0.15 & 0.31 & 0.25 & 0.16 & 0.10 & 0.03 & 0.00 \\
\hline $9 \mathrm{H}-2,12-14$ & 0.15 & 0.66 & 0.10 & 0.03 & 0.03 & 0.03 & 0.00 \\
\hline $10 \mathrm{H}-1,120-122$ & 0.25 & 0.28 & 0.25 & 0.14 & 0.08 & 0.00 & 0.00 \\
\hline $11 \mathrm{H}-4,24-26$ & 0.32 & 0.52 & 0.08 & 0.04 & 0.05 & 0.00 & 0.00 \\
\hline $12 \mathrm{H}-3,109-111$ & 0.48 & 0.31 & 0.04 & 0.03 & 0.07 & 0.08 & 0.00 \\
\hline $13 \mathrm{H}-5,71-73$ & 0.42 & 0.21 & 0.07 & 0.06 & 0.11 & 0.12 & 0.00 \\
\hline 14H-6, 69-71 & 0.59 & 0.15 & 0.06 & 0.04 & 0.08 & 0.08 & 0.00 \\
\hline $17 \mathrm{H}-2,125-127$ & 0.08 & 0.42 & 0.33 & 0.06 & 0.06 & 0.04 & 0.00 \\
\hline $17 \mathrm{H}-4,90-92$ & 0.20 & 0.43 & 0.14 & 0.06 & 0.07 & 0.09 & 0.00 \\
\hline $18 \mathrm{H}-1,63-65$ & 0.16 & 0.55 & 0.09 & 0.05 & 0.07 & 0.07 & 0.00 \\
\hline $18 \mathrm{H}-2,117-119$ & 0.18 & 0.55 & 0.09 & 0.05 & 0.07 & 0.07 & 0.00 \\
\hline $18 \mathrm{H}-3,41-43$ & 0.09 & 0.37 & 0.37 & 0.08 & 0.03 & 0.02 & 0.03 \\
\hline $19 X-4,11-13$ & 0.34 & 0.41 & 0.09 & 0.05 & 0.06 & 0.05 & 0.00 \\
\hline $19 X-4,34-36$ & 0.39 & 0.48 & 0.05 & 0.03 & 0.05 & 0.00 & 0.00 \\
\hline $20 \mathrm{X}-2,145-147$ & 0.17 & 0.33 & 0.33 & 0.10 & 0.04 & 0.02 & 0.00 \\
\hline $20 \mathrm{X}-3,111-113$ & 0.10 & 0.52 & 0.18 & 0.07 & 0.07 & 0.05 & 0.00 \\
\hline $21 X-1,70-72$ & 0.15 & 0.61 & 0.14 & 0.04 & 0.04 & 0.02 & 0.00 \\
\hline $21 X-2,76-78$ & 0.20 & 0.53 & 0.17 & 0.03 & 0.04 & 0.04 & 0.00 \\
\hline $22 X-1,143-145$ & 0.15 & 0.64 & 0.09 & 0.04 & 0.05 & 0.04 & 0.00 \\
\hline $22 X-4,113-115$ & 0.14 & 0.75 & 0.06 & 0.02 & 0.02 & 0.02 & 0.00 \\
\hline $22 X-5,30-32$ & 0.07 & 0.53 & 0.24 & 0.07 & 0.05 & 0.05 & 0.00 \\
\hline $23 X-1,32-34$ & 0.23 & 0.41 & 0.27 & 0.05 & 0.03 & 0.02 & 0.00 \\
\hline $24 X-4,32-34$ & 0.00 & 0.14 & 0.14 & 0.14 & 0.29 & 0.29 & 0.00 \\
\hline $29 X-2,15-17$ & 0.22 & 0.17 & 0.11 & 0.13 & 0.19 & 0.19 & 0.00 \\
\hline $33 X-6,84-86$ & 0.14 & 0.21 & 0.18 & 0.11 & 0.36 & 0.00 & 0.00 \\
\hline $33 X-6,111-113$ & 0.02 & 0.04 & 0.04 & 0.04 & 0.31 & 0.56 & 0.00 \\
\hline $34 X-1,85-87$ & 0.22 & 0.34 & 0.12 & 0.08 & 0.11 & 0.12 & 0.00 \\
\hline $35 X-8,1-3$ & 0.26 & 0.28 & 0.13 & 0.10 & 0.13 & 0.11 & 0.00 \\
\hline $36 X-1,85-87$ & 0.18 & 0.52 & 0.23 & 0.05 & 0.03 & 0.00 & 0.00 \\
\hline $37 X-3,146-148$ & 0.24 & 0.36 & 0.14 & 0.09 & 0.10 & 0.08 & 0.00 \\
\hline $37 X-6,81-83$ & 0.25 & 0.48 & 0.17 & 0.08 & 0.02 & 0.01 & 0.00 \\
\hline $38 \mathrm{X}-1,20-22$ & 0.21 & 0.24 & 0.18 & 0.15 & 0.15 & 0.09 & 0.00 \\
\hline $38 X-5,90-92$ & 0.27 & 0.53 & 0.07 & 0.04 & 0.05 & 0.05 & 0.00 \\
\hline $40 X-2,67-89$ & 0.21 & 0.58 & 0.10 & 0.05 & 0.04 & 0.03 & 0.00 \\
\hline $41 X-1,103-105$ & 0.33 & 0.49 & 0.08 & 0.04 & 0.06 & 0.00 & 0.00 \\
\hline $41 X-3,34-36$ & 0.10 & 0.36 & 0.25 & 0.11 & 0.11 & 0.08 & 0.00 \\
\hline $41 X-3,72-74$ & 0.09 & 0.36 & 0.26 & 0.12 & 0.10 & 0.07 & 0.00 \\
\hline $41 X-3,137-139$ & 0.18 & 0.40 & 0.21 & 0.09 & 0.09 & 0.03 & 0.00 \\
\hline $41 X-5,60-62$ & 0.27 & 0.55 & 0.12 & 0.03 & 0.02 & 0.02 & 0.00 \\
\hline $42 X-3,114-116$ & 0.18 & 0.50 & 0.17 & 0.07 & 0.05 & 0.03 & 0.00 \\
\hline $42 X-4,85-87$ & 0.27 & 0.11 & 0.08 & 0.08 & 0.20 & 0.24 & 0.00 \\
\hline $43 X-1,67-69$ & 0.29 & 0.16 & 0.11 & 0.10 & 0.18 & 0.16 & 0.00 \\
\hline 43X-CC, $28-30$ & 0.07 & 0.39 & 0.26 & 0.10 & 0.11 & 0.06 & 0.00 \\
\hline $44 X-4,34-46$ & 0.18 & 0.58 & 0.13 & 0.03 & 0.04 & 0.04 & 0.00 \\
\hline $44 X-6,79-81$ & 0.15 & 0.54 & 0.16 & 0.04 & 0.05 & 0.05 & 0.00 \\
\hline $45 X-1,64-66$ & 0.16 & 0.13 & 0.09 & 0.10 & 0.27 & 0.26 & 0.00 \\
\hline $45 X-1,135-137$ & 0.19 & 0.47 & 0.16 & 0.05 & 0.07 & 0.07 & 0.00 \\
\hline $46 \mathrm{X}-1,105-107$ & 0.01 & 0.08 & 0.14 & 0.19 & 0.38 & 0.20 & 0.00 \\
\hline $47 X-3,38-40$ & 0.27 & 0.45 & 0.09 & 0.07 & 0.06 & 0.05 & 0.00 \\
\hline $47 X-4,70-72$ & 0.37 & 0.37 & 0.07 & 0.05 & 0.07 & 0.07 & 0.00 \\
\hline $47 X-5,66-68$ & 0.14 & 0.46 & 0.22 & 0.06 & 0.06 & 0.05 & 0.00 \\
\hline $48 X-1,69-71$ & 0.34 & 0.46 & 0.07 & 0.05 & 0.07 & 0.00 & 0.00 \\
\hline $50 X-1,106-108$ & 0.26 & 0.46 & 0.11 & 0.05 & 0.06 & 0.06 & 0.00 \\
\hline $50 X-2,60-62$ & 0.17 & 0.30 & 0.20 & 0.10 & 0.11 & 0.11 & 0.00 \\
\hline $51 X-2,35-37$ & 0.37 & 0.37 & 0.09 & 0.07 & 0.11 & 0.00 & 0.00 \\
\hline $51 X-3,39-41$ & 0.27 & 0.16 & 0.13 & 0.11 & 0.16 & 0.16 & 0.00 \\
\hline $51 X-5,83-85$ & 0.28 & 0.19 & 0.17 & 0.13 & 0.13 & 0.11 & 0.00 \\
\hline $52 X-2,110-112$ & 0.32 & 0.23 & 0.15 & 0.10 & 0.11 & 0.08 & 0.00 \\
\hline $60 X-4,50-52$ & 0.30 & 0.39 & 0.10 & 0.08 & 0.13 & 0.00 & 0.00 \\
\hline $60 X-4,114-116$ & 0.43 & 0.36 & 0.06 & 0.03 & 0.06 & 0.06 & 0.00 \\
\hline $61 X-2,44-46$ & 0.32 & 0.28 & 0.09 & 0.08 & 0.12 & 0.12 & 0.00 \\
\hline $61 X-2,62-64$ & 0.22 & 0.21 & 0.16 & 0.12 & 0.17 & 0.11 & 0.00 \\
\hline $62 X-2,8-10$ & 0.21 & 0.29 & 0.18 & 0.10 & 0.12 & 0.11 & 0.00 \\
\hline $62 X-4,19-21$ & 0.26 & 0.52 & 0.09 & 0.07 & 0.07 & 0.00 & 0.00 \\
\hline $63 X-1,34-36$ & 0.45 & 0.16 & 0.08 & 0.08 & 0.12 & 0.12 & 0.00 \\
\hline $63 X-2,96-98$ & 0.22 & 0.17 & 0.14 & 0.13 & 0.18 & 0.16 & 0.00 \\
\hline 157-956A- & & & & & & & \\
\hline $10 \mathrm{H}-6,101-103$ & 0.10 & 0.17 & 0.16 & 0.18 & 0.24 & 0.16 & \\
\hline $11 \mathrm{H}-1,20-22$ & 0.45 & 0.33 & 0.07 & 0.03 & 0.05 & 0.07 & \\
\hline $11 \mathrm{H}-1,102-104$ & 0.30 & 0.32 & 0.14 & 0.11 & 0.14 & 0.00 & \\
\hline $11 \mathrm{H}-3,13-15$ & 0.54 & 0.31 & 0.05 & 0.03 & 0.03 & 0.03 & \\
\hline $11 \mathrm{H}-5,7-9$ & 0.55 & 0.29 & 0.05 & 0.04 & 0.04 & 0.04 & \\
\hline $11 \mathrm{H}-6,30-32$ & 0.51 & 0.25 & 0.06 & 0.04 & 0.07 & 0.08 & \\
\hline $14 \mathrm{H}-3,55-57$ & 0.32 & 0.42 & 0.09 & 0.05 & 0.06 & 0.06 & \\
\hline $14 \mathrm{H}-5,33-35$ & 0.23 & 0.60 & 0.09 & 0.03 & 0.03 & 0.03 & \\
\hline $14 \mathrm{H}-6,31-33$ & 0.23 & 0.10 & 0.07 & 0.19 & 0.31 & 0.10 & \\
\hline $16 \mathrm{H}-2,129-131$ & 0.23 & 0.31 & 0.13 & 0.08 & 0.13 & 0.13 & \\
\hline $16 \mathrm{H}-3,90-92$ & 0.48 & 0.28 & 0.05 & 0.05 & 0.07 & 0.08 & \\
\hline $16 \mathrm{H}-6,24-26$ & 0.42 & 0.36 & 0.07 & 0.04 & 0.06 & 0.06 & \\
\hline $16 \mathrm{H}-6,47-49$ & 0.36 & 0.50 & 0.07 & 0.02 & 0.05 & 0.00 & \\
\hline $17 \mathrm{H}-6,69-71$ & 0.19 & 0.21 & 0.22 & 0.16 & 0.14 & 0.08 & \\
\hline $17 \mathrm{H}-6,111-113$ & 0.26 & 0.25 & 0.18 & 0.12 & 0.12 & 0.08 & \\
\hline $1 \mathrm{R}-3,113-115$ & 0.36 & 0.52 & 0.04 & 0.02 & 0.03 & 0.03 & \\
\hline $7 R-4,110-112$ & 0.22 & 0.50 & 0.17 & 0.04 & 0.04 & 0.04 & \\
\hline $11 \mathrm{R}-2,13-15$ & 0.21 & 0.35 & 0.17 & 0.09 & 0.10 & 0.07 & \\
\hline $11 \mathrm{R}-2,118-120$ & 0.35 & 0.29 & 0.07 & 0.07 & 0.11 & 0.11 & \\
\hline
\end{tabular}


Appendix A (continued).

\begin{tabular}{lccccccc}
\hline $\begin{array}{l}\text { Core, section, } \\
\text { interval }(\mathrm{cm})\end{array}$ & $\begin{array}{c}<0.063 \\
(\mathrm{~mm})\end{array}$ & $\begin{array}{c}0.063 \\
(\mathrm{~mm})\end{array}$ & $\begin{array}{c}0.125 \\
(\mathrm{~mm})\end{array}$ & $\begin{array}{c}0.18 \\
(\mathrm{~mm})\end{array}$ & $\begin{array}{c}0.25 \\
(\mathrm{~mm})\end{array}$ & $\begin{array}{c}0.354 \\
(\mathrm{~mm})\end{array}$ & $\begin{array}{c}0.5 \\
(\mathrm{~mm})\end{array}$ \\
\hline 13R-2, 66-68 & 0.21 & 0.22 & 0.16 & 0.17 & 0.23 & 0.00 & \\
15R-3,33-35 & 0.27 & 0.23 & 0.10 & 0.10 & 0.15 & 0.15 & \\
16R-2, 77-79 & 0.19 & 0.40 & 0.16 & 0.09 & 0.09 & 0.07 & \\
16R-4, 67-69 & 0.23 & 0.32 & 0.18 & 0.12 & 0.09 & 0.07 & \\
17R-5, 137-139 & 0.14 & 0.21 & 0.24 & 0.17 & 0.14 & 0.11 & \\
18R-2, 60-62 & 0.38 & 0.16 & 0.09 & 0.07 & 0.15 & 0.15 & \\
21R-4, 38-40 & 0.40 & 0.22 & 0.11 & 0.11 & 0.17 & 0.00 & \\
21R-4, 130-132 & 0.19 & 0.22 & 0.15 & 0.12 & 0.15 & 0.17 & \\
21R-6, 37-39 & 0.05 & 0.13 & 0.15 & 0.20 & 0.28 & 0.19 & \\
24R-2, 47-49 & 0.21 & 0.31 & 0.16 & 0.10 & 0.11 & 0.11 \\
24R-4, 68-70 & 0.30 & 0.37 & 0.14 & 0.08 & 0.07 & 0.04 & \\
27R-4, 115-117 & 0.38 & 0.32 & 0.09 & 0.09 & 0.12 & 0.00 & \\
10H-6, 101-103 & 0.10 & 0.17 & 0.16 & 0.18 & 0.24 & 0.16 & \\
11H-6, 30-32 & 0.51 & 0.25 & 0.06 & 0.04 & 0.07 & 0.08 & \\
14H-3, 55-57 & 0.32 & 0.42 & 0.09 & 0.05 & 0.06 & 0.06 & \\
15R-3, 33-35 & 0.27 & 0.23 & 0.10 & 0.10 & 0.15 & 0.15 & \\
18R-2, 60-62 & 0.38 & 0.16 & 0.09 & 0.07 & 0.15 & 0.15 & \\
20R-6, 53-55 & 0.13 & 0.17 & 0.13 & 0.13 & 0.20 & 0.23 & \\
21R-4, 38-40 & 0.40 & 0.22 & 0.11 & 0.11 & 0.17 & 0.00 & \\
21R-4, 130-132 & 0.19 & 0.22 & 0.15 & 0.12 & 0.15 & 0.17 & \\
24R-3, 32-34 & 0.45 & 0.19 & 0.06 & 0.06 & 0.10 & 0.13 & \\
25R-1, 122-124 & 0.48 & 0.17 & 0.06 & 0.06 & 0.11 & 0.12 & \\
\hline
\end{tabular}

Note: Data shown as fraction of the total weight of sample. 
Appendix B. Petrographic data for selected samples from Sites 955 and 956.

\begin{tabular}{|c|c|c|c|c|c|c|c|c|c|c|c|c|c|c|c|c|c|c|c|c|c|c|c|c|c|c|}
\hline $\begin{array}{l}\text { Core, section, } \\
\text { interval }(\mathrm{cm})\end{array}$ & Qm & Qp & $\mathrm{Q}$ & $\mathrm{P}$ & $\mathrm{K}$ & F & Lvv & Lvf & Lvm & Lvl & $\begin{array}{l}\text { Pelagic } \\
\text { foram }\end{array}$ & $\begin{array}{l}\text { Benthic } \\
\text { foram. }\end{array}$ & $\begin{array}{l}\text { c Misc } \\
\text { bio frag }\end{array}$ & $\begin{array}{l}\text { Rnd carb } \\
\mathrm{g} \text { grains }\end{array}$ & $\begin{array}{l}\text { Plant } \\
\text { frag }\end{array}$ & $\mathrm{Px}$ & Amph & Pyrite & Biotite & $\begin{array}{c}\text { Alt } \\
\text { mafic }\end{array}$ & Glauc & Dolo & Zircon & Garnet & t Unknown & Zeolite \\
\hline 157-955A- & & & & & & & & & & & & & & & & & & & & & & & & & & \\
\hline $9 \mathrm{H}-2,12-14$ & 132 & 0 & 132 & 20 & 26 & 46 & 4 & 12 & 1 & 0 & 22 & 12 & 48 & 8 & 0 & 2 & 0 & 11 & 0 & 2 & 0 & 0 & 0 & 0 & 0 & 0 \\
\hline $10 \mathrm{H}-1,120-122$ & 2 & 0 & 2 & 2 & 2 & 4 & 229 & 0 & 0 & 0 & 47 & 1 & 7 & 0 & 0 & 1 & 0 & 1 & 0 & 0 & 0 & 0 & 0 & 0 & 0 & 0 \\
\hline $11 \mathrm{H}-4,24-26$ & 95 & 3 & 98 & 21 & 9 & 30 & 2 & 3 & 0 & 0 & 28 & 17 & 96 & 15 & 0 & 0 & 1 & 4 & 0 & 2 & 4 & 0 & 0 & 0 & 0 & 0 \\
\hline $12 \mathrm{H}-3,109-111$ & 134 & 1 & 135 & 14 & 3 & 17 & 0 & 0 & 0 & 0 & 38 & 11 & 26 & 0 & 1 & 2 & 0 & 55 & 1 & 10 & 0 & 1 & 0 & 0 & 0 & 0 \\
\hline $13 \mathrm{H}-5,71-73$ & 122 & 10 & 132 & 15 & 6 & 21 & 11 & 0 & 0 & 0 & 33 & 5 & 51 & 4 & 0 & 0 & 0 & 39 & 1 & 0 & 1 & 0 & 1 & 0 & 0 & 0 \\
\hline $14 \mathrm{H}-6,69-71$ & 87 & 1 & 88 & 8 & 3 & 11 & 0 & 0 & 0 & 12 & 5 & 0 & 2 & 0 & 0 & 0 & 4 & 176 & 1 & 1 & 0 & 0 & 0 & 0 & 0 & 0 \\
\hline $17 \mathrm{H}-2,125-127$ & 175 & 1 & 176 & 42 & 12 & 54 & 4 & 11 & 2 & 0 & 5 & 3 & 11 & 6 & 0 & 0 & 1 & 22 & 0 & 3 & 3 & 0 & 0 & 0 & 0 & 0 \\
\hline $17 \mathrm{H}-4,90-92$ & 194 & 3 & 197 & 29 & 12 & 41 & 4 & 11 & 0 & 0 & 5 & 0 & 27 & 2 & 0 & 1 & 0 & 4 & 3 & 0 & 3 & 0 & 2 & 0 & 0 & 0 \\
\hline $18 \mathrm{H}-2,117-119$ & 169 & 1 & 170 & 25 & 13 & 38 & 6 & 2 & 0 & 0 & 18 & 5 & 31 & 4 & 0 & 4 & 0 & 3 & 3 & 7 & 10 & 0 & 0 & 0 & 0 & 0 \\
\hline $18 \mathrm{H}-3,41-43$ & 169 & 0 & 169 & 36 & 21 & 57 & 0 & 10 & 3 & 0 & 3 & 10 & 29 & 6 & 0 & 1 & 0 & 7 & 3 & 1 & 1 & 0 & 0 & 0 & 0 & 0 \\
\hline $19 X-4,34-36$ & 236 & 0 & 236 & 14 & 6 & 20 & 0 & 0 & 2 & 0 & 14 & 4 & 11 & 0 & 0 & 0 & 1 & 6 & 1 & 3 & 0 & 0 & 0 & 0 & 0 & 0 \\
\hline $20 \mathrm{X}-2,145-147$ & 197 & 2 & 199 & 32 & 33 & 65 & 0 & 4 & 0 & 0 & 0 & 0 & 17 & 5 & 0 & 2 & 1 & 4 & 1 & 0 & 0 & 0 & 0 & 2 & 1 & 0 \\
\hline $20 \mathrm{X}-3,111-113$ & 187 & 0 & 187 & 27 & 20 & 47 & 0 & 6 & 1 & 0 & 3 & 8 & 24 & 11 & 0 & 2 & 2 & 8 & 2 & 0 & 0 & 0 & 0 & 0 & 0 & 0 \\
\hline $21 \mathrm{X}-2,76-78$ & 209 & 1 & 210 & 18 & 24 & 42 & 0 & 14 & 2 & 0 & 0 & 1 & 10 & 10 & 0 & 0 & 4 & $\begin{array}{l}0 \\
3\end{array}$ & 2 & 1 & 2 & 0 & 0 & 0 & 0 & 0 \\
\hline $22 \mathrm{X}-1,143-145$ & 224 & 1 & 225 & 16 & 23 & 39 & 0 & 7 & 3 & 1 & 0 & 4 & 12 & 6 & 0 & 0 & 0 & 2 & 0 & 0 & 1 & 0 & 0 & 0 & 0 & 0 \\
\hline $22 \mathrm{X}-4,113-115$ & 242 & 0 & 242 & 17 & 4 & 21 & 0 & 0 & 0 & $\begin{array}{l}1 \\
0\end{array}$ & 3 & 2 & 12 & $\begin{array}{r}0 \\
12\end{array}$ & 0 & 2 & 0 & 1 & 0 & 0 & 4 & 0 & 0 & 0 & 0 & 0 \\
\hline $22 \mathrm{X}-5,30-32$ & 221 & 2 & 223 & 23 & 9 & 32 & 6 & 3 & 0 & 0 & 2 & 1 & 16 & 4 & 0 & 0 & 1 & 6 & 2 & 0 & $\begin{array}{r}4 \\
3\end{array}$ & 0 & 1 & 0 & 0 & 0 \\
\hline $33 \mathrm{X}-6,84-86$ & 245 & 1 & 246 & 27 & 16 & 43 & 0 & 0 & 4 & 0 & 0 & 0 & $\begin{array}{r}10 \\
0\end{array}$ & 1 & 0 & 1 & $\begin{array}{l}1 \\
0\end{array}$ & 4 & 0 & 0 & 0 & 0 & $\begin{array}{l}1 \\
0\end{array}$ & 1 & 0 & 0 \\
\hline $33 \mathrm{X}-6,111-113$ & 246 & 0 & 246 & 19 & 16 & 35 & 2 & 3 & 2 & 0 & 1 & 0 & 4 & 0 & 0 & 1 & 1 & 4 & 0 & 1 & 0 & 0 & 0 & 0 & 0 & 0 \\
\hline $34 X-1,85-87$ & 196 & 0 & 196 & 22 & 15 & 37 & 1 & 3 & 0 & 1 & 9 & 4 & 16 & 5 & 0 & 0 & 0 & 22 & 0 & 4 & 2 & 0 & 0 & 0 & 0 & 0 \\
\hline $36 \mathrm{X}-1,85-87$ & 201 & 3 & 204 & 11 & 7 & 18 & 0 & 5 & 0 & 0 & 7 & 9 & 25 & 17 & 0 & 2 & 0 & 6 & 0 & 4 & 3 & 0 & 0 & 0 & 0 & 0 \\
\hline $37 \mathrm{X}-3,146-148$ & 105 & 2 & 107 & 16 & 5 & 21 & 4 & 2 & 0 & 0 & 58 & 14 & 74 & 8 & 0 & 0 & 1 & 2 & 1 & 0 & 8 & 0 & 0 & 0 & 0 & 0 \\
\hline $37 \mathrm{X}-6,81-83$ & 174 & 0 & 174 & 24 & 11 & 35 & 0 & 8 & 0 & 0 & 26 & 14 & 24 & 9 & 0 & 4 & 0 & 3 & 0 & 4 & 1 & 0 & 0 & 0 & 0 & 0 \\
\hline $38 \mathrm{X}-5,90-92$ & 229 & 0 & 229 & 34 & 6 & 40 & 0 & 8 & 0 & 0 & 1 & 1 & & 0 & 0 & 5 & 0 & 1 & 1 & 7 & 3 & 0 & 1 & 0 & 0 & 0 \\
\hline $40 \mathrm{X}-2,67-69$ & 229 & 3 & 232 & 24 & 9 & 33 & 0 & 0 & 0 & 4 & 2 & 0 & 1 & 3 & 0 & 0 & 2 & 5 & 4 & 2 & 11 & 0 & 1 & 0 & 0 & 0 \\
\hline $41 \mathrm{X}-1,103-105$ & 208 & 7 & 215 & 23 & 16 & 39 & 0 & 1 & 3 & 0 & 4 & 3 & 10 & 3 & 0 & 1 & 0 & 0 & 3 & 3 & 15 & 0 & 0 & 0 & 0 & 0 \\
\hline $41 X-3,34-36$ & 194 & 1 & 195 & 36 & 7 & 43 & 2 & 2 & 0 & 8 & 0 & 1 & 9 & 18 & 0 & 4 & 1 & 5 & 0 & 4 & 8 & 0 & 0 & 0 & 0 & 0 \\
\hline $\begin{array}{l}41 \mathrm{X}-3,34-50 \\
41 \mathrm{X}-3,72-74\end{array}$ & $\begin{array}{l}194 \\
173\end{array}$ & 4 & 177 & $\begin{array}{l}30 \\
22\end{array}$ & 13 & 35 & 10 & 2 & 5 & 15 & 5 & 3 & $\begin{array}{r}9 \\
19\end{array}$ & 11 & 0 & $\begin{array}{l}4 \\
5\end{array}$ & 0 & 5 & 1 & $\begin{array}{l}4 \\
3\end{array}$ & 7 & 0 & 0 & 0 & 0 & 0 \\
\hline 41X-3, 137-139 & 200 & 2 & 202 & 29 & 11 & 40 & 0 & 3 & 10 & 0 & 0 & 6 & 13 & 8 & 0 & 4 & 2 & 3 & 3 & 4 & 2 & 0 & 0 & 0 & 0 & 0 \\
\hline $41 X-5,60-62$ & 226 & 2 & 228 & 25 & 14 & 39 & 3 & 2 & 3 & 0 & 3 & 0 & 2 & $\begin{array}{l}0 \\
6\end{array}$ & 0 & 0 & 0 & 1 & 2 & $\begin{array}{l}4 \\
4\end{array}$ & $\frac{2}{7}$ & 0 & 0 & 0 & 0 & 0 \\
\hline $42 \mathrm{X}-3,114-116$ & 179 & 1 & 180 & 50 & 9 & 59 & 10 & 0 & 7 & 3 & 0 & 3 & 4 & 5 & 0 & 5 & 1 & 4 & 2 & 5 & 11 & 0 & 1 & 0 & 0 & 0 \\
\hline $42 X-4,85-87$ & 3 & 0 & 3 & 72 & 10 & 82 & 141 & 45 & 9 & 0 & 0 & 3 & 8 & 2 & 0 & 2 & 0 & 3 & 0 & 1 & 0 & 0 & 0 & 0 & 0 & 0 \\
\hline $43 X-1,67-69$ & 0 & 0 & 0 & 24 & 16 & 40 & 82 & 26 & 4 & 0 & 3 & 19 & 98 & 28 & 0 & 0 & 0 & 0 & 0 & 0 & 0 & 0 & 0 & 0 & 0 & 0 \\
\hline 43X-CC, $28-30$ & 202 & 1 & 203 & 28 & 16 & 44 & 8 & 7 & 4 & 0 & 0 & 0 & 4 & 13 & 0 & 1 & 1 & 1 & 3 & 5 & 8 & 0 & 0 & 0 & 0 & 0 \\
\hline $44 X-4,34-36$ & 188 & 0 & 188 & 34 & 25 & 59 & 1 & 5 & 5 & 0 & 0 & 1 & 3 & 6 & 0 & 1 & 0 & 15 & 4 & 1 & 11 & 0 & 0 & 0 & 0 & 0 \\
\hline $44 X-6,79-81$ & 181 & 1 & 182 & 27 & 14 & 41 & 0 & 10 & 1 & 0 & 2 & 6 & 35 & 6 & 0 & 0 & 1 & 2 & 0 & 2 & 12 & 0 & 0 & 0 & 0 & 0 \\
\hline $45 X-1,64-66$ & 1 & 0 & 1 & 18 & 90 & 108 & 52 & 49 & 2 & 0 & 6 & 11 & 52 & 6 & 0 & 2 & 0 & 9 & 2 & 0 & 0 & 0 & 0 & 0 & 0 & 0 \\
\hline $45 \mathrm{X}-1,135-137$ & 205 & 4 & 209 & 25 & 9 & 34 & 3 & 4 & 0 & 0 & 1 & 1 & 10 & 8 & 0 & 0 & 2 & 6 & 1 & 5 & 16 & 0 & 0 & 0 & 0 & 0 \\
\hline $47 X-5,66-68$ & 223 & 3 & 226 & 25 & 20 & 45 & 0 & 5 & 1 & 1 & 0 & 1 & 7 & $\stackrel{\circ}{2}$ & 0 & 1 & 1 & 0 & 1 & 1 & 7 & 1 & 0 & 0 & 0 & 0 \\
\hline $48 X-1,69-71$ & 208 & 2 & 210 & 7 & 2 & 9 & 0 & 1 & 0 & 1 & 17 & 12 & 15 & 1 & 0 & 1 & 0 & 8 & 1 & 2 & 22 & 0 & 0 & 0 & 0 & 0 \\
\hline $50 X-1,106-108$ & 176 & 1 & 177 & 25 & 17 & 42 & 5 & 0 & 0 & 0 & 23 & 13 & 28 & 3 & 0 & 0 & 1 & 4 & 0 & 0 & 5 & 0 & 0 & 0 & 0 & 0 \\
\hline $51 \mathrm{X}-2,35-37$ & 233 & 1 & 234 & 4 & 2 & $\begin{array}{r}42 \\
6\end{array}$ & 3 & 1 & 0 & 0 & 23 & 0 & 16 & 2 & 0 & 0 & 1 & $11^{4}$ & 0 & 1 & 3 & 0 & 0 & 0 & 0 & 0 \\
\hline $60 X-4,50-52$ & 220 & 0 & 220 & 17 & 10 & 27 & 1 & 0 & 2 & 2 & 9 & 1 & 20 & 2 & 0 & 2 & 1 & 9 & 2 & 0 & 2 & 0 & 0 & 0 & 0 & 0 \\
\hline $60 X-4,114-116$ & 228 & 2 & 230 & 18 & 11 & 29 & 5 & 1 & 0 & 0 & 4 & 2 & 8 & 7 & 0 & 0 & 1 & 9 & 1 & 1 & 3 & 0 & 0 & 0 & 0 & 0 \\
\hline $62 \mathrm{X}-4,19-21$ & 250 & 0 & 250 & 13 & 7 & 20 & 11 & 1 & 0 & 0 & 3 & 0 & 7 & 5 & 0 & 0 & 0 & 2 & 0 & 0 & 1 & 0 & 0 & 0 & 0 & 0 \\
\hline $157-956 \mathrm{~A}-$ & & & & & & & & & & & & & & & & & & & & & & & & & & \\
\hline $10 \mathrm{H}-6,101-103$ & 1 & 0 & & 38 & 5 & & 51 & 0 & 3 & 74 & 37 & 6 & 42 & 3 & 0 & 21 & 0 & 6 & 0 & 1 & 3 & 0 & 0 & 0 & 0 & 1 \\
\hline $11 \mathrm{H}-5,7-9$ & 93 & 3 & 96 & 31 & 6 & 37 & 0 & 0 & 0 & 2 & 42 & 7 & 56 & 10 & 0 & $\begin{array}{r}21 \\
0\end{array}$ & 0 & 47 & 3 & 4 & 2 & 0 & 0 & 0 & 0 & 0 \\
\hline $11 \mathrm{H}-6,30-32$ & 96 & 1 & $\begin{array}{l}90 \\
97\end{array}$ & 16 & 1 & 17 & 1 & 0 & 0 & 0 & 44 & 15 & 85 & 15 & 0 & 0 & 0 & 22 & 1 & 0 & 2 & 0 & 1 & 0 & 0 & 0 \\
\hline $14 \mathrm{H}-3,55-57$ & 136 & 4 & 140 & 30 & 7 & 37 & 0 & 0 & 0 & 0 & 26 & 4 & 68 & 6 & 0 & 1 & 0 & 7 & 3 & 3 & 3 & 1 & 1 & 0 & 0 & 0 \\
\hline $14 \mathrm{H}-5,33-35$ & 137 & 1 & 138 & 29 & 8 & 37 & 7 & 5 & 0 & 0 & 16 & 2 & 53 & 16 & 0 & 2 & 2 & 10 & 0 & 2 & 9 & 0 & 1 & 0 & 0 & 0 \\
\hline $14 \mathrm{H}-6,31-33$ & 1 & 0 & 1 & 97 & 0 & 97 & 123 & 0 & 0 & 55 & 6 & 0 & 0 & 0 & 0 & 10 & 2 & 2 & 0 & 0 & 0 & 0 & 0 & 0 & 0 & 4 \\
\hline $16 \mathrm{H}-2,129-131$ & 83 & 1 & 84 & 52 & 2 & 54 & 5 & 0 & 0 & 5 & 70 & 7 & 62 & 3 & 0 & 1 & 3 & 4 & 0 & 0 & 2 & 0 & 0 & 0 & 0 & 0 \\
\hline $16 \mathrm{H}-3,90-92$ & 149 & 1 & $\begin{array}{l}04 \\
150\end{array}$ & 29 & 6 & 35 & 0 & 0 & 0 & 0 & 7 & 1 & 27 & 2 & 0 & $\begin{array}{l}1 \\
0\end{array}$ & 27 & 0 & 1 & 1 & 4 & 0 & 0 & 0 & 0 & 0 \\
\hline $16 \mathrm{H}-6,47-49$ & 166 & 4 & 170 & 21 & 12 & 33 & 0 & 0 & 0 & 0 & 21 & 2 & 41 & 2 & 0 & 0 & 1 & 20 & 2 & 2 & 3 & 0 & 2 & 0 & 0 & 1 \\
\hline $17 \mathrm{H}-6,69-71$ & 0 & 0 & 0 & 78 & 0 & 78 & 13 & 0 & 0 & 97 & 12 & 0 & 17 & 0 & 0 & 78 & 0 & 4 & 0 & 0 & 0 & 0 & 0 & 0 & 0 & 0 \\
\hline
\end{tabular}


Appendix B (continued).

\begin{tabular}{|c|c|c|c|c|c|c|c|c|c|c|c|c|c|c|c|c|c|c|c|c|c|c|c|c|c|c|}
\hline $\begin{array}{l}\text { Core, section, } \\
\text { interval }(\mathrm{cm})\end{array}$ & Qm & Qp & Q & $P$ & $\mathrm{~K}$ & $\mathrm{~F}$ & Lvv & Lvf & Lvm & $\mathrm{Lvl}$ & $\begin{array}{l}\text { Pelagic } \\
\text { foram }\end{array}$ & $\begin{array}{l}\text { Benthic } \\
\text { foram. }\end{array}$ & $\begin{array}{l}\text { Misc } \\
\text { bio frag }\end{array}$ & $\begin{array}{l}\text { Rnd carb } \\
\text { grains }\end{array}$ & $\begin{array}{l}\text { Plant } \\
\text { frag }\end{array}$ & Px & Amph & Pyrite & Biotite & $\begin{array}{c}\text { Alt } \\
\text { mafic }\end{array}$ & Glauc & Dolo & Zircon & Garnet & Unknown & Zeolite \\
\hline \multicolumn{27}{|l|}{ 157-956B- } \\
\hline 1R-3, 113-115 & 154 & 1 & 155 & 36 & 17 & 53 & 18 & 0 & 0 & 0 & 11 & 4 & 35 & 4 & 0 & 1 & 0 & 13 & 1 & 2 & 0 & 1 & 0 & 0 & 0 & 0 \\
\hline $6 \mathrm{R}-3,45-47$ & 0 & 0 & 0 & 6 & 0 & 6 & 252 & 0 & 0 & 0 & 20 & 3 & 12 & 0 & 0 & 3 & 0 & 2 & 0 & 1 & 1 & 0 & 0 & 0 & 0 & 0 \\
\hline $7 \mathrm{R}-4,110-112$ & 110 & 1 & 111 & 27 & 15 & 42 & 53 & 5 & 0 & 8 & 19 & 10 & 31 & 2 & 0 & 7 & 1 & 1 & 0 & 8 & 1 & 0 & 0 & 0 & 1 & 0 \\
\hline $11 \mathrm{R}-2,118-120$ & 195 & 0 & 195 & 20 & 13 & 33 & 11 & 2 & 0 & 0 & 19 & 2 & 16 & 4 & 0 & 1 & 2 & 5 & 0 & 3 & 5 & 0 & 2 & 0 & 0 & 0 \\
\hline $15 R-3,33-35$ & 24 & 0 & 24 & 36 & 3 & 39 & 33 & 0 & 0 & 3 & 54 & 15 & 114 & 0 & 0 & 3 & 0 & 12 & 0 & 0 & 0 & 0 & 0 & 0 & 0 & 0 \\
\hline $18 \mathrm{R}-2,60-62$ & 146 & 1 & 147 & 59 & 5 & 64 & 0 & 0 & 0 & 0 & 6 & 4 & 47 & 2 & 0 & 0 & 2 & 11 & 1 & 4 & 9 & 1 & 2 & 0 & 0 & 0 \\
\hline $21 \mathrm{R}-4,130-132$ & 12 & 0 & 12 & 63 & 6 & 69 & 63 & 0 & 0 & 25 & 31 & 4 & 73 & 1 & 0 & 4 & 0 & 12 & 1 & 1 & 3 & 0 & 0 & 0 & 0 & 1 \\
\hline $21 \mathrm{R}-6,37-39$ & 0 & 0 & 0 & 25 & 16 & 41 & 64 & 0 & 0 & 5 & 121 & 11 & 46 & 6 & 0 & 2 & 1 & 2 & 1 & 1 & 0 & 0 & 0 & 0 & 0 & 0 \\
\hline $24 \mathrm{R}-3,122-124$ & 206 & 0 & 206 & 33 & $\begin{array}{r}10 \\
3\end{array}$ & $\begin{array}{l}41 \\
36\end{array}$ & $\begin{array}{r}04 \\
0\end{array}$ & 0 & 0 & $\begin{array}{l}3 \\
0\end{array}$ & $\begin{array}{r}121 \\
6\end{array}$ & $\begin{array}{r}11 \\
3\end{array}$ & $\begin{array}{l}40 \\
27\end{array}$ & $\begin{array}{l}0 \\
2\end{array}$ & 0 & 0 & $\begin{array}{l}1 \\
2\end{array}$ & 4 & 1 & $\begin{array}{l}1 \\
6\end{array}$ & 11 & 0 & 0 & 0 & 0 & 0 \\
\hline $25 \mathrm{R}-1,32-34$ & 227 & 0 & 227 & 22 & 4 & 26 & 0 & 0 & 0 & 0 & 5 & 2 & 19 & 2 & 0 & 0 & 1 & $\begin{array}{l}4 \\
3 \\
\end{array}$ & $\begin{array}{l}1 \\
0\end{array}$ & $\begin{array}{l}0 \\
6\end{array}$ & $\begin{array}{r}11 \\
8\end{array}$ & 0 & 1 & 0 & 0 & 0 \\
\hline $27 \mathrm{R}-4,115-117$ & 196 & 0 & 196 & 30 & 11 & 41 & 12 & 0 & 0 & 1 & 2 & 1 & 10 & 7 & 0 & 0 & 0 & 5 & 3 & 11 & 11 & 0 & 0 & 0 & 0 & 0 \\
\hline $48 \mathrm{R}-4,28-30$ & 0 & 0 & 0 & 7 & 0 & 7 & 70 & 0 & 0 & 0 & 60 & 1 & 136 & 0 & 0 & 14 & 0 & 2 & 0 & 2 & 1 & 0 & 0 & 0 & 0 & 0 \\
\hline
\end{tabular}

Notes: Numbers represent the number of individual grains/fragments counted. $\mathrm{Qm}=$ monocrystalline quartz, $\mathrm{Qp}=$ polycrystalline quartz, $\mathrm{Q}=$ total quartz $(\mathrm{Qm}+\mathrm{Qp}), \mathrm{P}=\mathrm{plagioclase}, \mathrm{K}=$ potassium feldspar, and $\mathrm{F}=$ total feldspar $(\mathrm{P}+\mathrm{K})$ $\mathrm{Lvv}=$ vitric volcanic lithic fragments, $\mathrm{Lvf}=$ felsitic volcanic lithics, $\mathrm{Lvm}=$ microlitic volcanic lithics, $\mathrm{Lvl}=$ lathwork volcanic lithics, Pelagic foram = globorotid, sphaeroidinella, and globigerinid foraminifers, Benthic foram $=$ benthic altered mafic grains, Glauc $=$ glauconite, and Dolo = dolomite.

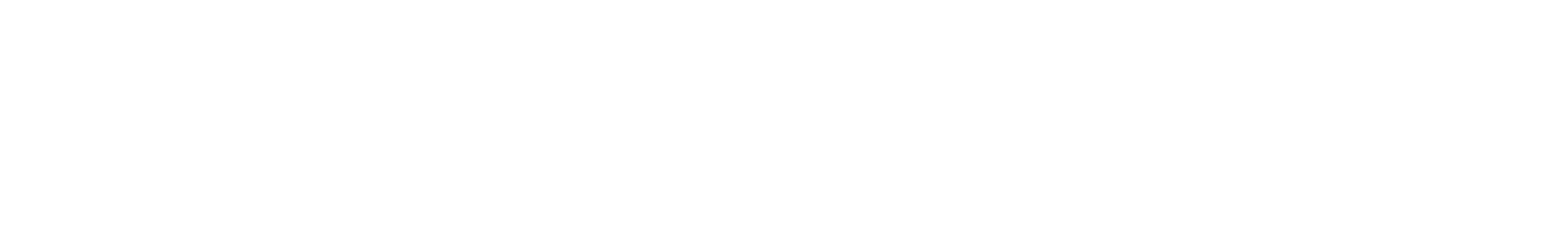

